\title{
Transfer Student Experiences and Identity Navigation in STEM: Overlapping Figured Worlds of Success
}

\author{
Austin L. Zuckerman ${ }^{\dagger}$ and Stanley M. Lo ${ }^{\dagger \neq \$ *}$ \\ ${ }^{\dagger}$ Division of Biological Sciences, 'Section of Cell and Developmental Biology, and \$Program in \\ Mathematics and Science Education, University of California San Diego, La Jolla, CA 92093
}

\begin{abstract}
Community colleges are a pathway in higher education for many students, including students who are pursuing baccalaureate degrees in science, technology, engineering, and mathematics (STEM). Because of the increased demand for professionals in the STEM workforce, a successful transition from community colleges to the university setting is essential for increasing the number of transfer students who complete STEM degree programs. Fostering a stabilized academic transition for transfer students requires an understanding of how different academic and sociocultural backgrounds can influence students' identity trajectories during their undergraduate education. In this study, Holland et al.'s framework of figured worlds was used to examine how transfer students pursuing STEM degrees negotiated their identities in their transition to the university. Because identity is a complex construct that can influence student experiences in STEM, this study examined areas of compatible and incompatible expectations of what constitutes success across the university, community college, and high school learning environments, and among students, families, and faculty. Inconsistent expectations across these figured worlds provide insight into the challenges associated with the community college to university transition that can affect transfer students' experiences and identity production at the university.
\end{abstract}

\section{INTRODUCTION}

Increased demand for professionals in the science, technology, engineering, and mathematics (STEM) workforce supports the recruitment and retention of larger student populations into STEM majors (President's Council of Advisors on Science and Technology, 2012; National Academies of Sciences, Engineering, and Medicine [NASEM], 2016). However, the number of trained professionals in STEM fields is expected to be insufficient. This gap can be partially attributed to insufficient opportunities in STEM majors, especially for minoritized populations ${ }^{1}$ such as first-generation (FG) college students and racial or ethnic minorities (Anderson and Kim, 2006; Dika and D'Amico, 2016; National Science Foundation, 2019).

More than $40 \%$ of undergraduates begin higher education at community colleges, and these students are disproportionately FG and/or racially or ethnically minoritized (Townsend, 2008; Hagedorn and Purnamasari, 2012; Bahr et al., 2013; Ma and Baum, 2016). Although community colleges represent a more accessible and affordable pathway for many students pursuing baccalaureate STEM degrees (NASEM, 2016), the

\footnotetext{
${ }^{1}$ We acknowledge that the term "minoritized" could encompass multiple intersecting dimensions of identities and backgrounds, e.g., gender, race and ethnicity, sexual identity and orientation, financial needs, FG college status, etc. We use the term "minoritized" modeled by Benitez (2010) to place emphasis on the process of student minoritization by higher education institutions, which includes and extends beyond exclusion by ethnicity and race (Asai, 2020), and to convey an understanding that "minority" is a social construct implemented within specific contexts. Much of the existing literature focuses on students from FG and racially or ethnically minoritized backgrounds.
}

Stephanie Gardner, Monitoring Editor Submitted Jun 19, 2020; Revised Jun 28, 2021; Accepted Jul 8, 2021

CBE Life Sci Educ September 1, 2021 20:ar48 DOI:10.1187/cbe.20-06-0121

*Address correspondence to: Stanley M. Lo (smlo@ucsd.edu).

(c) 2021 A. L. Zuckerman and S. M. Lo. CBE-Life Sciences Education ๑ 2021 The American Society for Cell Biology. This article is distributed by The American Society for Cell Biology under license from the author(s). It is available to the public under an Attribution-Noncommercial-Share Alike 3.0 Unported Creative Commons License (http://creativecommons.org/licenses/ by-nc-sa/3.0)

"ASCB®" and "The American Society for Cell Biology $\AA^{\prime \prime}$ are registered trademarks of The American Society for Cell Biology. 
experiences and institutional barriers of transfer students have been surprisingly understudied (Townsend, 2008; Laanan et al., 2010; Cohen et al., 2014; Schinske et al., 2017; Lo et al., 2019). Because transfer students represent a large and diverse yet neglected group of undergraduate students, it is particularly important to understand how the systemic and institutional experiences that students are presented with can impact their participation in STEM (Zamani, 2001; Flaga, 2006; Laanan, 2007; Mooney and Foley, 2011; Jackson et al., 2013; Dika and D'Amico 2016; Mooring and Mooring, 2016; Schinske et al., 2017; Lo and Mendez, 2019; Kanim and Cid, 2020).

While the literature is inconsistent in comparing persistence and degree attainment between transfer and non-transfer students, there is general agreement that non-transfer students experience greater academic success (Lakin and Elliott, 2016). Students transferring from community college to a 4-year university often experience "transfer shock," a phenomenon that leads to decreased academic performance and lower STEM completion rates due to an unstable academic transition, typically in the first term at the university (Hills,1965; Lakin and Elliott, 2016). Previous research suggests that lower completion rates in STEM may be due to ineffective guidance provided by institutions toward STEM degree pathways (Packard and Jeffers, 2013) and the academic and social challenges within the STEM cultural environment that students find unwelcoming and discouraging (Seymour and Hewitt, 1997; Reyes, 2011; Beasley and Fischer, 2012; Ramsey et al., 2013; NASEM, 2016; ). Socioeconomic barriers, insufficient resources in prior academic experiences, and negative interpersonal interactions with faculty and peers are factors that can adversely impact student motivation and performance (Laanan, 2007; Chang et al., 2011; Packard et al., 2011). Additionally, students who are accustomed to the institutional culture of community college may not be aware of the differences in norms between their 2- and 4-year institutions (Flaga, 2006; Townsend and Wilson, 2006; Chrystal et al., 2013). Persistence in higher education is contingent upon the ability of transfer students to negotiate their identities and adaptively respond to their new academic environment after transitioning to the university. However, there is a lack of literature that maps the trajectory of student identity during this critical academic transition.

Identity is a construct that accounts for complex interactions between sociocultural structures (e.g., gender, race, and ethnicity) and individual agency (Brickhouse, 2000). Although identity is often succinctly defined as becoming a "certain kind of person," institutional or interpersonal experiences and interactions can influence the trajectory of one's identity over time and context (Gee, 2000). Identity is shaped by one's perception of one's environment and the individuals with whom one interacts (Gee, 2000; Nasir and Saxe, 2003), and enculturation of students into the university is dependent on how students make meaning of their experiences and equilibrate who they are and who they want to ultimately become (Carlone and Johnson, 2007). Encouraging student participation in STEM at the university level requires supportive experiences that help students foster a stable science identity and affirm a sense of self-efficacy and engagement in their learning (Carlone and Johnson, 2007; Hazari et al., 2013; Jackson and Seiler, 2013; Seymour and Hunter, 2019).
An in-depth examination of student identity is needed to understand how students' experiences and access to opportunities influence their identity trajectories during their undergraduate education. Undergraduate education represents a critical transitional stage during which students make important decisions regarding their careers. To make a quality STEM education more accessible and welcoming to an increasingly diverse undergraduate population, it is essential for educators to create spaces where students can cultivate meaningful identities and challenge marginalizing narratives that limit their access to STEM communities (Solorzano et al., 2000; Case and Hunter, 2012; Ong et al., 2018). Although transfer students represent a large and diverse population of undergraduate students pursuing STEM, their identity-forming experiences have been understudied in the literature. This study contributes to the gap in the literature by examining transfer students' experiences and understanding of what constitutes success as they author and reconfigure their identities in the university. This identity construction and transformation was studied by analyzing the differences in how transfer students assign meaning to their academic and social experiences across different academic stages. Using figured worlds as a theoretical framework (Holland et al., 1998), this study addressed the following research questions (RQs):

1. How do transfer students define and contrast their understanding of success across three different educational contexts: university, community college, and high school?

2. How do students' perceptions of family and faculty expectations relate to their own understanding of university norms?

\section{THEORETICAL FRAMEWORK Figured Worlds}

To ground our understanding of transfer student identity navigation during the transition to university, this paper applies the concept of figured worlds (Holland et al., 1998). Figured worlds are abstract realms that describe identity production in a specific space or context, and this framework has previously been used in research on student experiences and engagement in learning at the undergraduate level (Urrieta, 2007). The structure of these culturally reproduced spaces can be defined by systems of social reproduction that are sustained by actors who configure their identities in relation to cultural norms and practices (Bourdieu and Passeron, 1990; Holland et al.,1998). For example, the higher education classroom is a space with norms that have been historically situated and passed through generations (Le et al., 2019). Educators and students are actors who construct their attitudes, behaviors, and identities in relation to these norms. These historically situated norms reinforce existing implicit hierarchies that may not be inclusive or welcoming to the minoritized populations that transfer students encompass (Ladson-Billings and Tate, 1995; Harper, 2013; Walkington, 2017; Ong et al., 2018). Higher education spaces were originally accessible to the global wealthy elite, which typically privileged individuals from culturally dominant backgrounds who were then able to accumulate cultural knowledge, status, and power across generations (Patton, 2016). The norms and structures have historically sustained competitive, individualistic, and solitary practices that reflect White, Western values (Ong et al., 2018). The cultural disconnect that originates from these 


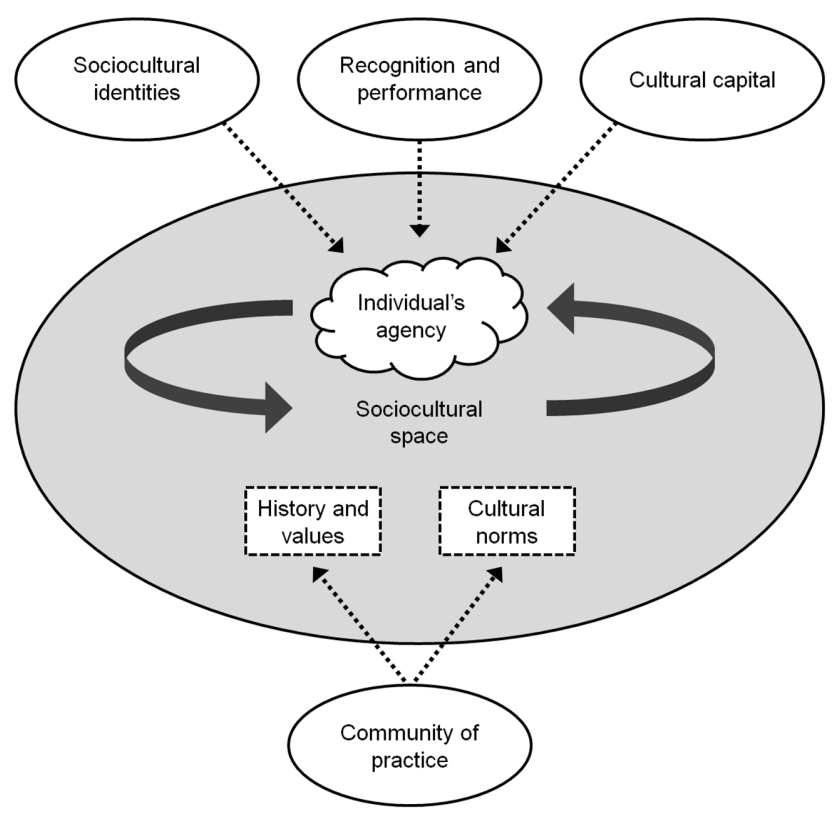

FIGURE 1. Interacting elements of a figured world. An individual's figured world (curved dark gray arrows) represents the individual's agency for identity negotiation in relation to a sociocultural space (large light gray oval), which is defined by its history, values, and cultural norms. Based on existing literature, our proposed model integrates frameworks related to these interacting elements, including sociocultural identities, recognition and performance, cultural capital, and community of practice, and can be used to explain an individual's agency and/or the sociocultural space.

historically defined norms marginalizes the cultural values and community cultural wealth of students from minoritized backgrounds and identities (Yosso, 2005). Figured worlds primarily focus on an individual's agency in a sociocultural space, and agency is contextualized by sociocultural history and values that can privilege or oppress certain identities across time and context (Holland et al.,1998; Brickhouse, 2000; Nasir and de Royston, 2013; Figure 1).

A figured world lens reveals how meaning and engagement are shaped by shared repertoires of resources and broader sociocultural structures and discourse (Holland and Lave, 2009; Chaffee and Gupta, 2018). Figured worlds are not static; these worlds are produced and evolved by the individuals acting within them. Meaning is assigned to certain artifacts and identities, and cultural values change over time (Holland et al., 1998; Urrieta, 2007; Nasir and de Royston, 2013; Langer-Osuna, 2015; Esmonde and Booker, 2016). For example, the university can be interpreted as a figured world with norms and values that are historically cultivated, evolved, and sustained by faculty and administrators. Through extensive experiences and interpretation of these experiences, individuals begin to embody and position themselves according to the norms and values within these worlds (Holland et al., 1998). However, figured worlds are not constructed in isolation. Experiences and participation in one figured world can influence behaviors and identity navigation in another figured world, as entry may involve multiple figured worlds intersecting in one space (Calabrese Barton et al., 2013; Price and McNeill, 2013; Langer-Osuna, 2015).
Because students shape their present and future goals by drawing upon previous life and academic experiences, there are often points of continuity and discontinuity between meanings and expectations across figured worlds (Price and McNeill, 2013). Therefore, one's sense of identity in a new figured world can be negatively impacted if cultural knowledge and values are not transferable. For example, in a case study examining how middle school girls from minoritized backgrounds engaged in science-related activities, Calabrese Barton et al. (2013) found that a particular student's sense of science identity in the classroom was comprised of racial dynamics that did not allow her to capitalize on her love for experiments and project work that developed during her earlier schooling experiences. For many minoritized students of color, a combination of marginalizing sociohistorical narratives and the normative and structured practices of schooling ultimately undermine their sense of creativity and meaningful engagement in science (Caraballo, 2019).

Conversely, the ability to capitalize on one's cultural knowledge and experiences can confer a positive identity trajectory in a new figured world (Bourdieu, 1997). For example, when Calabrese Barton and Tan (2010) investigated the developing agency of youth who participated in an urban community science club, the club was a space where youth were able to identify themselves as knowledgeable "community science experts," and these students were able to connect their home and community experiences, resources, and relationships to the practices and discourses within their figured worlds of the scientific community. Enacted through the rightful presence framework, these experiences require intentional community practices that support restructuring implicit power dynamics toward social justice, making visible both injustice and the necessary social change (Calabrese Barton and Tan, 2019, 2020). Analyzing how students traverse figured worlds and negotiate their identities in relation to sociocultural structures gives a more comprehensive insight into how students interpret and author their academic and social identities across time and context (Jurow, 2005).

\section{Related Identity Frameworks}

In addition to the mechanisms of identity production outlined in the figured worlds framework, other frameworks have been used to examine student identity negotiation in different educational contexts. Several of these frameworks examine how students navigate through cultural spaces and configure their identities based on their perceptions of their academic and social experiences (Figure 1). We will briefly summarize examples of different frameworks that contextualize the roles of two salient dimensions of figured worlds, agency and sociocultural spaces, on identity production across time and context.

First, Carlone and Johnson (2007) applied a science identity model that examined the experiences of successful women of color in science. This model captured the identity trajectories of these women within three interrelated dimensions: competence, performance, and recognition (Carlone and Johnson, 2007). Similarly, quantitative models of student identity across STEM disciplines focused on competence and performance as one dimension, recognition as a second dimension, and interest as a third dimension (Hazari et al., 2010, 2013; Cribbs et al., 2015; Godwin et al., 2016; Hosbein and Barbera, 2020). 
Paralleling the figured worlds framework, the interaction of the three dimensions in these models demonstrated that identities can be formed in practice and are grounded in sociocultural patterns and behaviors that can either enable or constrain a positive identity trajectory. However, these models also acknowledge that identities may also become habituated as individuals become accustomed to patterns of performance and recognition over time (Carlone and Johnson, 2007).

Second, because individual identity trajectories involve navigation through complex sociocultural structures, figured worlds can also be related to frameworks that integrate the roles of cultural and social capital. Social capital refers to the social networks and connections that can provide benefits and mobility in attaining status within a sociocultural space, and cultural capital includes the legitimized knowledge, behaviors, dispositions, or habits drawn from home and community resources that confer privilege and advantage when navigating complex systems (Bourdieu, 1977, 1997; Vryonides, 2007). These forms of capital include the cultural and social competencies embedded within institutions that enhance individual mobility across different contexts (Bourdieu, 1997; Edgerton and Roberts, 2014). Inequitable access to these forms of capital can ultimately lead to varying degrees of participation and agency in a figured world, thereby perpetuating disparities in socioeconomic and educational outcomes.

Finally, figured worlds as a framework is similar but not identical to the concept of community of practice. A community of practice is the foundation of a social learning system that is defined by norms and values shared by a community (Lave and Wenger, 1991, Wenger, 2010). A community of practice implies that the positioning of one's identity is a collaborative process that is grounded in a mutual understanding of competence between members of the community. Newcomers to the community may embody practices and identities that can either complement or conflict with the community's shared practices (Lave and Wenger, 1991; Wenger, 1998; Handley et al., 2006). Participation in the community depends on the ability to negotiate meaning within a shared domain through a shared repertoire of resources and practices (Wenger, 1998). The community of practice can therefore be construed as a shared social world in which participants collectively determine the standard practices and behaviors that are to be upheld in the learning community (Wenger, 1998; Biza et al., 2014; Farnsworth et al., 2016).

The concept of figured worlds is more focused on how individuals can author themselves in a social space, and these individual identities are negotiated by the social norms and expectations within the sociocultural space that is defined by the community of practice. The individual positioning of one's identity within this space is also influenced by expectations drawn from previous life and community experiences (Holland et al., 1998; Price and McNeill, 2013). For example, a university can be interpreted as a community of practice that is defined by a historical yet evolving repertoire of academic expectations. However, the university is also an individually defined figured world for students. The individual identity negotiation and figuring within this space is based on the ability of students to leverage and bridge their cultural and academic backgrounds and experiences to develop a sense of agency and engage in the shared practices of the university community. Collectively, these different frameworks provide complementary insights into the relationship between identity navigation in a sociocultural space and the structures that can support or restrict a positive identity trajectory (Figure 1).

\section{Identity-Forming Experiences}

Studies of identity are often centralized around agency, but the figured worlds framework also examines the complex interplay of agency with institutional and cultural norms and personal backgrounds and experiences. Given that the figured worlds construct has previously connected identity to classroom learning and engagement in both K-12 and higher education (e.g., Langer-Osuna, 2015; Le et al., 2019), this construct can be used to gain a fundamental understanding of how students author or position their identities across different contexts and in relation to sociocultural norms (Holland et al., 1998; Urrieta, 2007; Chang, 2014). Identities are often negotiated when navigating through sociocultural spaces, and students pursuing STEM may need to reconfigure who they understand themselves to be if traditional teaching practices are perceived to promote a narrow range of identities (Costa, 1995; Holland et al., 1998; Carlone and Johnson, 2007; Rubin, 2007). The ways that students recognize their positions can vary, as the perceived sociocultural norms and expectations may differ across figured worlds (Holland et al., 1998; Calabrese Barton et al., 2013). The outcomes within these figured worlds can be uncertain due to the dynamic nature of student identity and the subjective interpretations of their academic experiences (Urrieta, 2007; Calabrese Barton et al., 2013).

Because agency interplays with one's experiences and perceptions of institutional norms and values, figured worlds provide a useful framework for studying student experiences and identity formation across different academic transitions. Identity formation during an academic transition relies on students gaining a fundamental understanding of the sociocultural norms within a new academic space (Holmegaard et al., 2014). It is especially important to understand the challenges that minoritized students face in these transitions. These students often possess capital that is not valued by the sociocultural and sociohistorical institutions of the university, leading to greater challenges in configuring their identities as they navigate the university (Saunders and Serna, 2004; Yosso, 2005; Azmitia et al., 2013; Cherng et al., 2013; Moschetti and Hudley, 2015). This struggle in identity navigation should not be interpreted as an inherent student deficit but rather due to higher education institutions placing minoritized students in disadvantaged positions by providing insufficient resources or individuals with authority (such as faculty) holding biased assumptions about these students (Steele and Aronson, 1995; Torres et al., 2010; Spencer et al., 2016; Harrison and Tanner, 2018).

Minoritized students are often more vulnerable to negative stereotypes or racialized experiences that may cause them to be more stigma-conscious and lower their educational prospects (Chang et al., 2011). Because community colleges serve as a gateway in higher education for minoritized groups such as FG students or students from racially or ethnically minoritized backgrounds (Rendon and Mathews, 1989; Hagedorn et al., 2008; Crisp and Nunez, 2014), the marginalizing experiences that minoritized students face are observed in the experiences of many transfer student populations. Many transfer students 
are also stigmatized as "latecomers to science" because they initially embark on alternative pathways following high school due to poor academic performance, a lack of interest in a science career, economic and familial obligations, or other unique personal circumstances (Jackson and Seiler, 2013). In their initial transition from community college to a 4-year institution, transfer students may experience a discontinuity or disruption in their academic and social identities. Implementing identity negotiation strategies to validate their sense of belonging and agency in the university community largely depends on their access to support networks from family, peers, and faculty (Ethier and Deaux, 1994; Berzonsky and Kuk, 2000; Azmitia et al., 2013; Holmegaard et al., 2014). However, when these students eventually enter the university, they may not be provided with access to a sufficient number of resources or opportunities to capitalize on their experiences and align their sense of self with the norms and practices of the university community.

Although not a focal point of this study, individuals position themselves within a figured world depending on the power, privilege, and status they are afforded in a sociocultural space (Holland et al., 1998; Urrieta, 2007). The range of identities that can be negotiated is often institutionalized by individuals who have power. Transfer students face an onus of navigating through potentially restrictive academic environments with less time to positively negotiate, resist, or reframe their identity trajectories than students who enter the university directly from high school. It can therefore be argued that transfer students should not be required to reconfigure their identities to conform to the norms and values of the university, especially if traditional institutional practices do not welcome a broad range of student identities (Scanlon et al., 2007). However, because identity is a complex and dynamic construct, it may not be feasible for institutions to implement practices that can universally accommodate all dimensions of student identity. Despite this restriction, educators and administrators are obligated to develop equitable and inclusive spaces that allow students to shape a positive identity trajectory in the university; it is essential to develop institutional practices that, at minimum, guide transfer students through their transition from community college into the university (Case and Hunter, 2012; Ong et al., 2018). These institutional practices should introduce transfer students to resources that cultivate academic and mentorship experiences that help them individually construct and navigate their sense of identity and belonging within the university community (Graham et al., 2013; Jackson and Seiler, 2013).

To better understand the challenges that transfer students face, this study applies Holland et al.'s (1998) framework of figured worlds to examine the experiences and identity navigation of transfer students in their transition from community college to university. Student perceptions of success inform their goal orientation and ultimately influence their affective, behavioral, and cognitive outcomes (Nerstad et al., 2020). As students configure their identities along educational trajectories, these outcomes can change their agency and motivation. Because an individual's agency is contextualized by norms and values in a sociocultural space, transfer students' figured worlds of success will be used to understand how their interpretations of institutional norms and values influenced their identity production in the university.

\section{METHODS}

\section{Study Participants}

This study took place at a public university in the western United States, described by the Carnegie Classification of Institutions of Higher Education (McCormick and Zhao, 2005) in the category of very high research activity and with a 4-year, full-time, more selective, and higher transfer-in undergraduate profile. Participants for this study were selected from a 6-week summer bridge program that provided transfer students with an intensive introduction to scientific research in the summer before their first quarter at the university. Participants were required to commit at least 8 hours per day to the program activities on all weekdays. The program also provided opportunities for participants to network with faculty and to explore campus resources that would introduce them to other research and professional opportunities in STEM.

Participants were selected from the first three cohorts of the program (8-13 students per cohort; 31 total students across all three cohorts). Factors considered for admission into this program included the completion of introductory biology course work in community college and interest in graduate or professional studies in STEM research; FG college students and students from a group underrepresented in STEM were particularly encouraged to apply. To recruit students, informational flyers were sent by a central campus mailing list to community colleges. Program faculty also hosted an informational session during a transfer recruitment event at the university. All applicants were required to submit a letter of recommendation from a science instructor who could advocate their potential for a summer research program. Program acceptance rates were approximately $15-20 \%$ of all applications. Of the 31 participants, 15 had attended community colleges within driving distance of the university, and 14 were in other cities within the same state as the university. The remaining two students transferred from out of state. Geographic location of community college was not a selection criterion for admission into the program. However, the program required students to travel to campus on weekdays, which may have prompted more local applications. Sixteen different in-state community colleges were represented by our participant sample, and nearly all community colleges had articulation agreements with the university. Across the various community colleges, the average rate of students who transfer to a 4-year institution is approximately $12 \%$, with a range of $8-20 \%$. The program faculty regularly coordinated and facilitated meetings and informal social events with participants after the summer. Approximately $75 \%$ of the students across the three cohorts availed themselves of these events while still attending the university. Because the program was designed to prepare students for undergraduate research opportunities, many participants had gained new mentorship in a faculty laboratory following the program. Regardless, the program faculty were accessible for advising and mentorship for the remainder of the participants' academic careers at the university.

Access to the summer bridge program resulted in a convenient sample (Patton, 1990). The participants arguably had considerable supports from the program to navigate their transitions to the university, and we acknowledge that these opportunities may have narrowed their definitions of success. All 31 participants in this program were invited for an interview. A 
TABLE 1. Aggregate demographics of study participants

\begin{tabular}{lrr}
\hline Demographics & Number & Percentage \\
\hline Gender & 16 & \\
Women & 12 & 45 \\
Men & 1 & 3 \\
Transgender man & & \\
Race or ethnicity & & \\
Hispanic or Latinx & 9 & 31 \\
Middle Eastern & 6 & 21 \\
Asian & 5 & 17 \\
Asian and White & 3 & 10 \\
Hispanic or Latinx and White & 3 & 10 \\
White & 2 & 7 \\
African American or Black & 1 & 3 \\
College generation status & \\
First generation (FG) & & \\
Continuing generation (CG) & 22 & 76 \\
Field of study & 7 & 24 \\
Biological sciences & & \\
Cognitive science & 13 & 45 \\
Engineering or computer science & 7 & 24 \\
Social sciences & 4 & 14 \\
Physical sciences & 2 & 7 \\
Health sciences & 1 & 3 \\
Mathematics & 1 & 3 \\
\hline
\end{tabular}

aparticipants who are at least partially of Hispanic or Latinx, Middle Eastern, or African-American or Black descent were considered minoritized.

${ }^{\mathrm{b}} \mathrm{FG}$ status is designated as neither parent nor guardian having received a 4-year university degree in the United States.

total of 29 agreed to participate in the interview, resulting in a final response rate of $93 \%$. Even though some participants had switched majors after the summer bridge program, all of them remained in a STEM discipline (Table 1). At the study institution, there are multiple specializations of each major. While some of the disciplines may not be universally categorized as STEM, all participants with these majors had a specialization with a STEM focus, for example, cognitive science or psychology with a neuroscience specialization.

A substantial fraction $(24 / 29$ or $83 \%)$ of these participants were FG and/or from a racially or ethnically minoritized background (Table 1). In this study, students who were fully or partially from Middle Eastern, Hispanic or Latinx, or African-American descent were considered minoritized in terms of racial or ethnic background. We acknowledge that it is regrettable to group students with distinct cultural experiences into one category; this grouping is typically done due to low representation of these identities in comparison to White populations. Community colleges also typically have a diverse range of ages, with a large population of students who are parents or have economic and familial responsibilities that delay enrollment (Ma and Baum, 2016). However, data on participant birth dates are not available, as this information was not considered for admission into the program or required to be collected for reporting purposes. Based on informal conversations between the program coordinators and the participants, it is estimated that more than $50 \%$ of the students were nontraditional college age ( $>24$ years old), reflecting the diverse age ranges typically observed in community college and transfer student populations.

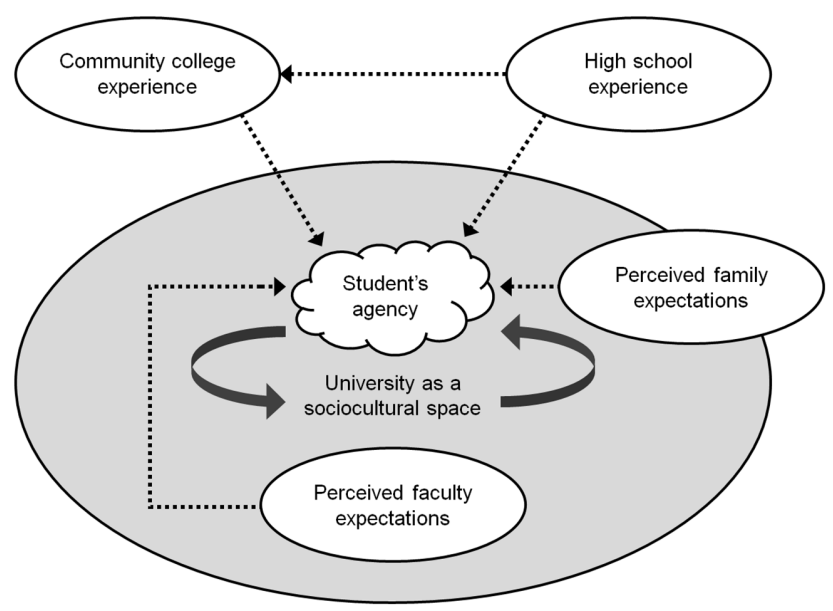

FIGURE 2. A transfer student's figured world of the university. University, community college, and high school represent different (and potentially overlapping) figured worlds in three distinct educational spaces. An individual student's agency in the university sociocultural space is contextualized by the individual's community college and high school experiences, which contribute to the cultural capital that students bring with them, as well as expectations for what might constitute as performance and thus garner recognition. Sociocultural identities and cultural capital are embedded within perceived family expectations, and students may draw on their perceived faculty expectations to infer the cultural norms, history, and values of the university. Therefore, the family's and faculty's figured worlds of the university also contribute to a student's agency, thus intersecting with the student's figured world in the university as a sociocultural space.

The participants were interviewed approximately 2 years after the conclusion of the summer bridge program, which was near their target graduation dates, with the intention that the participants would have accumulated most of their university experiences. This allowed for an interview protocol that prompted participants to compare their academic and social experiences across their university, community college, and high school learning environments.

\section{Data Collection}

A semistructured interview protocol was implemented as part of a larger study that examined various aspects of the participants' university and community college experiences (Supplemental Material). The interview questions for this study prompted participants to define their perceptions of success across three academic figured worlds: university, community college, and high school (Figure 2). These educational contexts represent three different figured worlds in three distinct educational spaces. Questions regarding the participants' high school experiences were also included to gain a more comprehensive examination of their identity trajectories in their pathways to higher education. Within each of these three educational spaces, the participants were prompted to: 1) define success as a student, 2) describe what makes a student successful, and 3) provide specific examples of what a student does to achieve success. To further identify differences in academic expectations of success across these three spaces, the participants were also prompted to elaborate if their definition of a successful 
student had changed following their academic and social experiences at the university. Articulation of this change relied on retrospective accounts of their previous experiences in community college and high school. All participants were able to recall and describe examples of what successful students do in each of these contexts.

In this study, the university figured world was the central focus. Because families offer cultural expectations that can influence the educational mobility, attitudes, and behaviors of students in the university (Bryan and Simmons, 2009), we compared how participants perceived their families would define success as a university student. Participants were prompted to: 1) define how they thought that their families would define success at the university, 2) explain the expectations that their families had for them at the university, and 3) specify what their families' expectations were for them after they graduated. After the first set of interviews, it was noted that faculty were sometimes referenced indirectly in the students' figured world of success in the university. An additional set of interview questions were included to explore how participants perceived faculty expectations of student success in the university to directly examine how these expectations intersected with the students' figured world of success. Participants were asked to articulate their perceptions of how faculty would define success and what students specifically do that gets recognized by faculty as being successful. The figured worlds of family, faculty, and the student represent three figured worlds intersecting in one educational space: the university (Figure 2).

\section{Data Analysis}

The interviews ranged from 20 minutes to 59 minutes in length (with an average of 34 minutes) and served as the primary source for an interpretative qualitative analysis. Interviews were transcribed semi-verbatim by a professional transcription service that removed non-lexical utterances such as "um" and "uh." For the preliminary analysis, segments of the interviews were annotated with brief notes and labels that described salient trends and analytical insights, and a summary was written for each participant's full interview (Miles and Huberman, 1984). After iterative close reading of the interview transcripts, analytical codes and memos were generated. In vivo codes were derived from participants' own phrases (Saldaña, 2015) to succinctly summarize the metrics of success collectively defined within each figured world. These codes provided a common connotation to the most salient trends and variations that emerged from the data (Saldaña, 2015). The codes were applied to participant responses for each individual figured world.

To achieve theoretical saturation, data were collected over a period of 3 years. Following the constant comparative method, the coding process began as data were collected, and code definitions were consolidated and revised as the number of interview samples increased (Corbin and Strauss, 2015; Aldiabat and Le Navenec, 2018). Additional codes were generated to capture new patterns observed in the data. No additional codes or patterns were identified in the data collected from the third year, and the number of interviews conducted fell within the estimated range that would achieve code saturation (Hennink et al., 2017). After verifying that all significant trends were noted in the interview samples, we then developed broader categories inductively by grouping codes together. Linkages between the categories gave rise to three main themes described in the Results and Discussion section. These themes summarized the most salient analytical insights emerging from the interview responses.

\section{Reliability, Trustworthiness, and Positionality}

The interviews were conducted as part of a larger study examining transfer students' academic and research experiences. A subset of interviews (12/29 or 41\%) were coded by two researchers (A.L.Z. and S.M.L.) for the larger study, with an interrater agreement of $87.5 \%$ and a Cohen's kappa of 0.82, indicating substantial to almost perfect agreement (Cohen, 1960; Landis et al., 1977). All disagreements within this subset of interviews were resolved through dialogic discussions to reach consensus. Given the high reliability, one researcher (A.L.Z.) proceeded with coding all the interview responses. Excerpts from these remaining interviews were discussed with a second researcher (S.M.L.) to verify that the preliminary codes succinctly and accurately summarized the connotations of the interview responses. The second researcher also reviewed the excerpts selected in the Results and Discussion section. Regular meetings between the two researchers corroborated that the interpretations of the interview responses were consistent and that the excerpts aptly represented the themes that emerged from the analysis. All analyses and interpretations were discussed until full consensus was reached. Additionally, research findings were presented to various communities of discipline-based education researchers; education researchers; and STEM researchers at national conferences, research meetings, and thesis committees. Incorporating feedback from these sources verified that interpretations and claims were grounded in the data.

The interviews were conducted by two White graduate students (one man and one woman) who had not previously interacted with the participants. We acknowledge the possibility that the sociocultural identities of the interviewers may have influenced the participants' comfort and willingness to share their experiences and perspectives. The interviewers were intentional in not reacting outwardly to participants' responses (diSessa, 2007), and participants were told that they could stop the interview at any point if they felt uncomfortable. All participants opted to complete the full interview.

In terms of positionality, the first author (A.L.Z.) identifies as a White American with one parent who is college educated. He had no prior interactions with the participants or involvement with the program, allowing for a more objective interpretation of the students' perspectives and experiences. The second author (S.M.L.) identifies as a 1.5-generation Chinese Canadian who came to the United States as an undergraduate student to pursue higher education in STEM. While his parents are college educated, the intersectionality based on his immigrant family status may have resulted in cultural capital (required to navigate the university process) more similar to FG students. He occasionally interacted with the participants at program social events and presented a faculty research talk to one of the cohorts. Both authors had some community college experience when they were undergraduate students.

\section{RESULTS AND DISCUSSION}

The commonalities and variations in the participants' experiences are illustrated through selected excerpts from the 
TABLE 2. Participants with selected interview excerpts ${ }^{a}$

\begin{tabular}{lllll}
\hline Pseudonym & Generation status & Race and ethnicity & Gender & Field of study \\
\hline Antonio & FG & Latino and White & Man & Biological sciences \\
Cameron & CG & Asian and White & Man & Biological sciences \\
Claire & CG & White & Woman & Cognitive science \\
Isabella & FG & Latina & Woman & Biological sciences \\
Maria & FG & Latina & Woman & Biological sciences \\
Mateo & FG & Latino & Man & Biological sciences \\
Mona & FG & Middle Eastern & Woman & Health sciences \\
Ryan & CG & Asian and White & Mansender man & Social sciences \\
Terrance & CG & Black & Man & Cognitive science \\
Yosef & FG & Middle Eastern & Woman & Computer science \\
Zahra & FG & Middle Eastern & Biological sciences \\
\hline
\end{tabular}

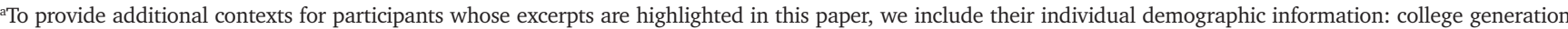
status defined as FG or CG, race and ethnicity, gender, and field of study.

interview data. Each participant articulated the areas of incompatible expectations across the university, community college, and high school learning environments, as well as those among students, families, and faculty. The selected excerpts highlight the idiosyncrasies of our unique study sample and the specific institutional cultures that they navigated in their educational trajectories. Although our data illustrate a spectrum of student experiences, these findings are not intended to provide universally generalizable information. We acknowledge that other students from other institutions with different cultural norms will likely have unique identity-forming experiences that were not observed in our study. However, these excerpts serve as exemplars from contextually rich interviews (Flyvbjerg, 2006) to provide insights into different ways that transfer students could individually author and reconfigure their identities during their transition into the university.

Mapping the trajectory of transfer students' identities during their transition from community college to university contributes to an understanding of how different academic and cultural backgrounds and social experiences can affect student identity production across time and context. Identity formation in a figured world relies on an understanding of how individuals position themselves in relation to the sociocultural norms defined in that space. All students in this study sample individually assigned meaning to their identities and experiences in many unique ways. For each figured world in our model, excerpts from a subset of participants are presented to show how individual transfer students may negotiate and reconfigure their identity trajectories as they navigate through the transition to university. These participants collectively provided responses that were broadly representative of the commonalities and variations of success described in each figured world. They also represented a range of demographics (e.g., race, ethnicity, gender, FG status) within the study sample (Table 2). Pseudonyms have replaced all names in these case studies to maintain participant confidentiality.

First, we describe how participants contrast their understanding of success across their university, community college, and high school figured worlds. Then, we examine how these participants articulate their perceptions of family and university faculty expectations in relation to their own understanding of success in the university. Defining a relationship among different figured worlds in distinct educational spaces (university, community college, and high school) or among different figured worlds in the same space (student, family, and faculty in the university) is based on overlap or misalignment among the defined metrics of success within each figured world (Figure 2). The commonalities and variations in how success is defined across these figured worlds are consolidated into three main themes: 1) grades are not everything, 2) contrasting roles of the family, and 3) variable metrics of success among faculty. These themes are summarized and supplemented with additional excerpts to reinforce the nuanced perspectives and analytical insights that were collectively contributed by the participants in our study sample.

\section{RQ1: Figure Words of Different Academic Spaces}

Figured World of University. When articulating their understanding of success at the university, many participants emphasized the importance of developing interest in the subject matter of their studies. Discovering a concrete purpose for pursuing their field of study was perceived to be essential for breaking out of a cycle of arbitrary learning. For example, Mona stated:

I would definitely say that first is having a clear vision of what you want at the end is extremely important. So, if I still didn't know what I wanted to do, then I don't think that I would've been very successful because I would've found a hard time being passionate about the subject I'm learning, because it's all random. No clear vision of what I want from my life.

Instead of solely focusing on completing academic requirements, participants articulated success as finding an emotional connection and personal meaning in their educational pursuits. A common mechanism to achieve this was by building social connections and participating in relevant academic experiences. For example, Yosef articulated that building connections proved to be a more significant asset for him than achieving high grades, as the former conferred greater opportunities to cultivate meaningful experiences in his major.

Realize that the numbers aren't everything. Make connections with everyone possible, and also, just have a passion for what you do. One of the examples that I would give is the fact that I personally always sit at the front of the classroom, but I always talk to the professor who is teaching either before or after the 
class is taught. And that has made me, you know, more familiar with the faculty, and I think that opens up opportunities. ... And, so it just, you expanding who you know affects what you're going to be able to do so much. Because even if you, even if you know your shit, even if you know what you're doing, not knowing people is not going to take you that far.

Increased engagement from building connections and experiences allowed these participants to enter a space where they could imagine, or figure, themselves toward meaningful aspirations in the university. Many participants articulated that high grades were an incomplete representation of success. Although high grades were sometimes regarded as a tangible metric of academic competence, participants did not recognize grades as a determinant that would ultimately give them a clearer vision of their trajectories and aspirations beyond the university. The enriching experiences and applicable skills were perceived to confer greater purpose to their academic and professional endeavors. For example, Isabella stated that before she entered the university, she defined success exclusively by high grades. However, the challenges that she faced at the university and the inspiration she received from seeing others persist in the face of adversity are the primary factors that influenced her new definition of success.

I think I would define it as a student who is resilient and who, like, persists despite of, like, the challenges that they face. So, not a matter of exactly what their grades are, you know, like, say, like, if a student, like, failed a class or something, but how they like overcame it basically. ... I think, before, I thought success was just like grades. And I think I grew a lot from then because, like, I don't know. ... It's like, yeah, so I think for sure, I think, just, like, all the challenges I've faced here. I think seeing people that I admire and, like, that I define as, like, being successful is different from what I thought was. ... I just think I have a higher appreciation for students who are resilient as opposed to students who just do well academically.

Isabella's new definition of success demonstrates that she had entered a space in the university where she recognized growth and resilience as valuable for her personal and academic development. Observing concrete instances where other students had overcome adversity and continued to progress toward a successful trajectory prompted her to deprioritize the importance of grades. Her realization that grades were an incomplete representation of success reflects an emerging sense of agency after discovering new opportunities for growth and achievement in her figured world of the university.

Even in cases in which high grades were considered as a primary metric of success in the university, participants also acknowledged that the ability to connect and apply one's academic knowledge beyond a traditional classroom setting was equally (if not more) significant. For example, Maria stated:

I would define it as someone who comes out of [the university] not just with good grades, but also with experience and with, um, you know mentorship and knowledge. Yeah, maybe also someone who isn't just or isn't just knowledgeable in their major but also in other fields. ... They volunteer or intern in labs. You know they could put school as a priority but also not let it take over their lives.
Despite the perception that high grades may be an established norm of success that is needed to progress toward more advanced opportunities, many participants articulated that they were still able to recognize other metrics of success beyond academic performance. For example, Cameron argued that a critical understanding of course material and providing mentorship to one's peers is an ideal metric of success. However, he simultaneously acknowledged that a high-grade point average (GPA) is a conflicting and more recognized metric of success within this figured world:

Well, I think you're successful in learning the material if you can teach the material to someone else. But obviously success is if you can get an "A." Personally, I don't settle for anything less than an "A." Even an "A," I'm not happy with. "A" or " $\mathrm{A}^{+}$," that's what I aim for. But that's the real bummer, right, of the education system, is that, like, everything is so grade based. So, when I teach a [discussion] section, right? No one, not very many people, I'm not going to say no one, not very many people care about the actual learning part. They just want to know what they have to memorize for the test, and then can they forget it, and then get away with that for the rest of their life. Right? Everything is just grade based. But I think you're successful if you can learn it and teach someone else. That would be the ideal system. Right? But obviously it's measured by GPA.

After reconfiguring their understanding of success at the university, participants recognized that exploring and preparing for advanced opportunities in their fields was imperative for their personal and intellectual development. However, this understanding of success was not as mature during their initial transition into the university. Before progressing toward this more nuanced conception of success, high grades appeared to be in the foreground of their university figured worlds. However, extensive practical experiences in their STEM majors allowed participants to engage in meaningful experiences and cultivate an enduring sense of identity in their educational trajectories at the university. This is exemplified in Yosef's evolved understanding of success. He originally measured success strictly by grades. Although his current definition of success minimizes the importance of grades, he states that his passion for his major and his desire to build connections and experiences had enhanced his academic performance.

After realizing that there are a lot of people at the school that get "A's" in everything, that is not my definition of success anymore. Because, for me, the definition of success is what is it that makes you unique. What is it that makes you, you know, stand out. When, like, people say, this person is successful, they can't say that everyone with a 4.0 is successful because that isn't necessarily a good criterion when you have so many people. I feel like success is something that's more specific. More, this person is successful over others because they have done this and not just that. And I feel like I've stopped caring that much about [it]. It's weird, because I still have a 4.0, but I don't care about it. It's more like, it's kind of like a side effect to caring about everything else and succeeding at everything else that, that just happens versus focusing more on that.

Yosef's evolved definition of success demonstrates that he had entered a space where he felt a sense of fulfillment and 
authentic scholastic achievement. After accessing opportunities where he could develop a stronger personal connection to his field of study, he was able to author an identity that was driven by values that were more purposeful to his academic and professional development.

After identifying experiences that stabilized their feelings of competence and achievement, participants were able to negotiate their previous prioritization of grades. Participants came to the realization that grades alone would not confer the same opportunities for recognition and personal fulfillment. They progressed toward new definitions of success after developing a sense of agency that sustained their academic growth and allowed them to construct more meaningful academic aspirations and identities in the university.

Within this expanded definition of success, participants did not state that grades are unimportant; rather, they collectively articulated that grades were an incomplete metric that should not be substituted for meaningful practical experiences and networking opportunities in their majors. Because no participant directly articulated that grades should be completely disregarded, it is likely that grades were still configured as at least partially important in their figured worlds of success at the university. However, there was no consensus or articulation of a specific cutoff grade or GPA that is perceived as successful. Although some participants (e.g., Cameron) set personal goals to achieve the highest grades possible, most participants implied that grades do not have to be perfect for a student to be successful in the university.

Figured World of Community College. When navigating within their figured worlds of community college, participants retrospectively described a narrower and more simplistic understanding of success. In community college, the participants were overall more focused on achieving high performance in their academic course work. For example, Maria relates:

I was focused on, you know, just being at the top of the class and didn't really much pay attention to stuff that was going on outside. You know, social issues and stuff like that. And being here at [the university], I realized that, you know, you don't have to be top of the class to be a good student or a successful student.

Maria perceived a restricted vision of student engagement in community college. After transferring to the university, she became more cognizant that her education could be applied to opportunities linked to broader social issues. However, because she perceived that her academic identity was constrained to normative standards of academic evaluation, she may not have been aware of existing opportunities in community college. A perception of limited opportunities outside the classroom ultimately restricted her from progressing toward personally enriching academic endeavors until she transferred to the university.

Although high grades were the central focus in how many participants thought about success in community college, strong academic performance did not necessarily translate to achieving meaningful engagement within their academic studies. For Mona:
[Success was] just grades. Yeah, I mean, I don't really think that. Yeah, it was a very dispassionate environment to be in [laughs]. I don't know. Everyone has a different experience at community college, but I felt like I wasted a lot of time. You're not really surrounded by the same people, so community college, a lot of people tend to want the easy way out or they tend to want less difficult exams or they always complain about the professor. But the environment [at the university] is really different. Students are more driven and motivated to learn the materials.

Mona's perception of a "dispassionate environment" indicates that she did not cultivate the same agency at community college as she had when navigating the university. After experiencing a new sociocultural environment in the university, Mona had entered a space where she perceived that developing passion and meaningful experiences were reinforced as institutional norms. Unlike in community college, she felt a sense of agency that inspired her to adopt these more purposeful metrics when authoring her identity trajectory in the university.

The perception of a different academic culture in community college may be due to a perceived difference in cultural norms and values. Existing literature has highlighted a social stigma that depicts transfer students as being academically underprepared for course work in 4-year universities. This stigma is derived from a perception of community colleges as being less rigorous and academically inferior (Laanan et al., 2010; Chin-Newman and Shaw, 2013; Shaw et al., 2019). Terrance, for example, may have shared this stigma, as he perceives that the expectations for a community college student are far lower than a university student. He believes that merely passing and transferring to a university would be the primary metric of success in his community college. This perception of a successful community college student was influenced by his observation that many community college students in his hometown were unable to complete these minimum expectations.

The expectations are far lower there, so I think that passing is the [mark] for, you know, success. I think that not dropping out is success. I think getting an [associate's degree] or transferring to a four-year university and completing that is like the gold standard of success because I don't think that the majority of people that go into community college, do that.

A perceived difference in academic norms and expectations indicates that some participants may have experienced a disconnection in their understanding of success across their university and community college figured worlds (Table 3 ). However, a misalignment between the community college and university figured worlds is not necessarily a generalized phenomenon for all transfer students. For example, Isabella identified herself as being a good student in community college and believed that she had a strong sense of community due to her ability to work efficiently with other students and build connections with faculty. Her metric of success in this figured world is more defined by grades, as she perceives that high grades are a primary determinant for transferring to the university. However, she also articulates that building connections and being involved in different opportunities are a source of confidence that is instrumental in the transition from community college to university. 
TABLE 3. Different roles of grades and experiences ${ }^{a}$

\begin{tabular}{lcc}
\hline Figured world & \multicolumn{1}{c}{ Role of grades } & Role of experiences \\
\hline University & $\begin{array}{c}\text { Grades are an incomplete representation of success that } \\
\text { should not undermine the importance of building } \\
\text { relevant experiences and connections. }\end{array}$ & $\begin{array}{c}\text { Academic experiences and connections are essential for } \\
\text { cultivating meaningful aspirations in the university } \\
\text { community. }\end{array}$ \\
Community college & $\begin{array}{c}\text { High grades are prioritized due to importance in } \\
\text { advancing toward the next academic stage. } \\
\text { High school }\end{array}$ & $\begin{array}{c}\text { Experiences are not readily available or are not directly } \\
\text { relevant to long-term aspirations. }\end{array}$ \\
& advancing toward the next academic stage. & $\begin{array}{c}\text { Experiences improve social standing but are not directly } \\
\text { relevant to long-term aspirations. }\end{array}$ \\
\hline
\end{tabular}

${ }^{a}$ The most salient descriptions of the role of grades and experiences across the three different educational spaces. Configuration of community college and high school shows strongest overlap across the three figured worlds.

I think there, I always thought, like, success was like getting good grades and transferring into a good university. I think that, like, I felt like that defined my success. Also, being involved with different opportunities, and I think just doing well in your classes. It was, I don't know, I think that's what I defined success as. I was very, I guess like a lot of people, they really looked up to me at community college. So, I had, like, everyone knew me for being a good student, like everyone. So, I think it was just different, my experience there.

Because the participants articulated variations in the extent to which the metrics of success defined in their community college and university figured worlds were similar or overlapping, we speculate that community colleges may not be uniform in academic expectations or in the amount of academic and professional resources provided.

Figured World of High School. Although the central goal of this analysis is to configure the identity trajectory of transfer students across the community college to university transition, the participants were also prompted to articulate their figured worlds of success in their respective high schools. High school represents a critical educational space that lies along the continuum of students' academic trajectories. Experiences in high school may establish expectations that may be incorporated into transfer students' figured worlds of academic success when navigating through community college or the university.

Configurations of the community college and high school figured worlds revealed a fundamental overlap in the role of quantitative measures of academic achievement on the construction of the participants' academic identities (Table 3). Emphasis on grades when thinking about success was conversely undermined after participants had the opportunity to engage in meaningful academic and practical experiences in the university. However, several participants perceived that performing well academically in high school was essential for advancing toward the next academic stage. The participants construed that their academic identities were driven by an obligation to conform to high educational standards measured by grades and standardized examinations. Although high grades were perceived to be a norm for defining success within this academic space, this achievement did not necessarily translate to engagement in meaningful intellectual and personal growth experiences. For example, Terrance articulated that the overarching goal in high school is to ultimately gain admission into a 4-year university. Although he desires to see a focus on the cultural and creative growth of the individual, he feels that the secondary education system embodies quantitative metrics of success. These metrics undermine the cultivation of critical-thinking skills that he perceives are essential for success in the university.

I don't agree with [high school's] version of success. I think it's very quantitative and misses a lot of the important aspects of what makes a successful student. For me, a successful student is someone who is able to be above average on all of those things, that they, on tests, standardized tests, and SATs. You know, if you're above average, that is success. If you get in a 4-year university, that is success. But I think that they failed to take into account things like cultural growth and creative growth. And so, they would not really care what sort of grades you got in a Spanish class or in an art class or in a music class, and that was disappointing that they didn't worry or weren't concerned with the holistic growth of an individual.

Maria highlights that the norms for defining success in high school were constrained by peer influence. Although she perceived that focusing on academics in high school is important, the agency to progress toward high academic performance may be limited by unmotivating peer interactions.

Honestly that's going to be hard for me to answer because high school wasn't that great, and that's why I went to community college. But I guess as a high school student, when you're successful, it means that you're not just influenced by your peers, you know, doing bad stuff. You're focused. You're taking your classes seriously because you know that maybe it doesn't mean anything to you right now, but in the future, it's going to mean a lot. I mean graduating from university and going and having your career that you love. So just, I guess thinking beyond just high school is what makes high school students successful.

She retrospectively describes her high school experience as suboptimal, and this may be due to her perception that the benchmarks for success were much lower and did inspire her to author meaningful academic interests along her identity trajectory.

For Claire, active involvement in extracurricular activities was pivotal for success in high school. However, she sees involvement more geared toward nonacademic interests. Her overall figured world of a successful high school student is more focused on achieving basic academic competence to progress toward her long-term academic and career goals. She sees a positive social environment through active involvement in extracurricular activities as instrumental for achieving high grades, which she perceives are a gatekeeper for progressing toward the next stage of her academic career. 
In terms of a goal, it was always to go to a [university]. So I'd say success was getting a good GPA and to be in the top of the class. ... I think that in high school, to be successful, you need to, I feel like [social dynamics] are really important in high school, and a lot of people would be like, "You need to do academics. You need to study all the time." And I think in high school, if you have a bad social environment, you're going to have a bad time, and that's going to affect your grades. So being able to have a solid social group and be involved in different aspects, like sports or theater, all will inherently get your grades higher in high school because [social dynamics] are so important.

Although success in the participants' community college and high school figured worlds often showed stronger overlap than the university due to the perceived importance of grades, a metric of success that was unique to high school was social standing (Table 3). For example, Yosef recognizes that success in high school is more dependent on grades, but he also mentions the tendency for high school to measure popularity as a parameter of success:

At high school, I feel like success was also strictly related to the grade. I was in [another country] back then, and it was the IB system, so I'm pretty sure it's an entirely different perspective from the people who are here. Yeah, its success was more about being social than it was about, it was about the grade, but it was also about, you know, who was, as all high schools are, who was more popular, who was more social. I feel like that is an indicator for who's successful in high school. ... But then, that doesn't apply anywhere after because, who cares if you're popular or not in college.

Because Yosef perceives that the popularity metric of success does not apply after high school, there is a partial lack of overlap between his high school and community college figured worlds.

Although social acceptance among peers and teachers was a common source of self-efficacy and positive identity formation in high school, popularity was often given a negative connotation. Difficulty in fulfilling or conforming to this norm was perceived to undermine a positive identity trajectory and overall sense of belonging. For example, Isabella previously described a strong sense of social community in her community college that was instrumental for her academic and emotional transition into the university. However, she did not experience this sense of community in her high school. She did not perceive that anyone in her high school was interested in her future success, and the only accomplishment she could identify was a timely graduation.

I went to a high school that really didn't prepare me at all for college. Like at all. When I transferred, like, I was on the lower math, lower English, lower everything. So, like, I had to start from the bottom. So, success for me was just, I guess graduating because I was, like, very forgotten at my high school. Like, nobody, like, cared about, you know, my success. I remember, like, my senior year, like, having no plan, and I had to reach out to my teacher and, like, it was really difficult to even do that. And so, I think success for me in high school is actually just, like, graduating and just continuing from there.
In Isabella's perception, she was invisible in high school, a space that did not provide her with sufficient recognition experiences. Her limited agency in the figured world of high school did not allow her to develop a clear vision of success. She perceived a lack of accessible resources that would have guided her toward meaningful academic aspirations. Isabella implies that lack of access to capital in high school led to enduring discontinuities in her academic preparation and expectations when navigating through her figured worlds of community college and the university.

Theme: Grades Are Not Everything. When constructing their figured worlds of success in the university, the participants in this study articulated a strong sense of identity after participating in experiences and engaging in interpersonal interactions that were relevant to their personal and academic development. This allowed them to develop a sense of agency in their academic learning experiences and reimagine success as authentic engagement in their learning rather than the fulfillment of arbitrary academic requirements. However, when the participants were prompted to define success as a student in community college, high grades were perceived as the highest priority. The initial focus on high grades likely relates to the perceived importance of grades in the transfer process. Because high grades are perceived as the primary metric that determines university admission, some participants felt constrained to adhering to this single measure of success throughout their community college experiences. For example, as Antonio succinctly summarized:

Success in community college is getting a 4.0 [GPA]. Because your entire purpose in life at that point is to transfer somewhere. That's, that should be the entire goal. To get straight "A's." For defining, like, success as a community college student, that's what I would say.

Participants who described high grades as being in the foreground of success in their community college figured worlds had authored their identity trajectory to comply with a norm that they perceived would advance them toward the next stage of their academic careers. However, achieving high grades did not necessarily allow the participants to develop positive identities or cultivate meaningful experiences in their academic trajectories. Following their transition to the university, participants expanded their figured worlds of success to include other metrics, and many participants articulated that their overall definitions of success as a student had at least partially changed over the course of their university experiences. After being fully immersed in the university community, participants realized that high grades did not necessarily confer the same opportunities for personal growth or positive identity formation as did building relevant experiences and social connections in their majors. Even in cases in which participants emphasized high grades, this benchmark of success was often supplemented with other metrics, such as proactively applying academic knowledge and building professional experiences. Conversely, through a reflection of their community college experiences, some participants claimed that there were limited opportunities to explore their academic interests and build relevant academic experiences. For example, Ryan stated: 
At community college, it's harder because there's not as many opportunities outside of the classroom to develop your interests. For me, if I wanted to work at a lab, I had to go over to [another university]. There was nothing at my community college for me to do. And luckily it was, you know, virtually across the street, so that wasn't a big like sacrifice. But there are, like, lots of clubs at community college. The most valuable volunteer experience I ever had was at community college. And so, there are ways to get involved. But it does take a little bit, I think, more effort than it does here at [the university].

Because the opportunities to build relevant academic experiences in community colleges are perceived to be limited, the emphasis on achieving high grades became more pronounced for many participants. The participants articulated that research and mentorship experiences seem to be more naturally integrated into the university than in community college. Although alternate extracurricular and volunteer opportunities are present in community college, community college students pursuing STEM may perceive that they are not able to construct experiences that are directly relevant to their fields of study. In some cases, this may be due to limited opportunities for research and other professional experiences.

The different meanings assigned to grades across the community college and university contexts reflects an additional form of "transfer shock" that is not experienced by non-transfer students. A previous study that examined the high school to university transition of students from racially and ethnically minoritized backgrounds highlighted that grades are often used as a guiding metric for students to assess their success in navigating the academic system in a higher education institution (Hurtado et al., 2007). Grades have also been linked to outcome-focused emotions that impact student engagement, and the literature often triangulates grades, motivation, and other metrics of social and academic belonging to measure student adjustment during the first year (Pittman and Richmond, 2008; Kahu et al., 2015; Stephens et al., 2014). However, student recognition of grades as an incomplete measure of success in the university has not been a salient observation in this literature. Even if non-transfer students experience incompatible expectations in the high school to university transition, they have considerably more time to navigate the norms of the university and reconfigure their figured worlds of success. In contrast, transfer students navigate through an additional higher education institution before transitioning to the university, so they may adopt the perceived norms and values of the culture from that first sociocultural space when thinking about the behaviors and practices needed to succeed in the university that they transition into. Because transfer students experience an additional institutional culture in which high grades may be recognized and rewarded as a demonstration of academic competence, the perceived reinforcement of high grades in a higher education institution may lead to greater shock or disorientation as they reconfigure their figured worlds of success and academic identities in the university.

Figured worlds illustrate that socially constructed identities involve a complex interplay between agency and one's perception of institutional and sociocultural norms. Transfer students who are not provided with opportunities to explore their academic interests beyond the classroom in community college may configure high grades as the primary determinant of aca- demic competence in their figured worlds of the university. Defining high grades as a benchmark of success could be influenced by a multitude of academic experiences and interpersonal interactions in high school and community college that reward and recognize high grades as a demonstration of strong academic performance. Because identities can be shaped by positive recognition experiences (Carlone and Johnson, 2007), students who receive positive reinforcement for high grades may habituate their identities to align primarily with this one metric of academic success. However, these identities may not ultimately align with the norms and values of the university. The misalignment indicates that the transition to the university can be particularly difficult for transfer students who have limited exposure or access to mentorship and practical experiences that introduce them to the dynamic and rigorous expectations established within the university community. Although this study was primarily focused on examining the community college to university transition, participants were also asked to define success as a student in high school to elucidate points of overlap or misalignment between their high school, community college, and university figured worlds. Overall, the responses indicate that there were lower expectations in high school. However, there appears to be a stronger overlap between the community college and high school figured worlds in the emphasis on high grades. Several participants articulated that high grades in high school are the primary determinant of a successful transition into the next stage of their academic careers.

Like in community college, the available extracurricular opportunities are also not perceived to be necessarily related to the development of academic interests. Participation in high school extracurricular activities is more motivated by a desire to achieve high social standing, a metric of success that is more unique to the high school figured world. Students who use their agency to position themselves as popular in high school may purposefully disengage from their learning if they feel that the culture of academics would hinder their social mobility and sense of belonging (Shanahan, 2009). Likewise, high school students who feel pressured to do well on quantitative metrics of academic achievement may enact agency that rejects other opportunities for academic enrichment. High grades are a norm of success that rewards competence and mobilizes students toward the next stage of their educational trajectories (Tocci, 2010; McMorran et al., 2017). However, the pressure to achieve high grades may reduce student creativity, critical thinking, and the motivation to invest time and energy toward developing authentic academic and career interests. Without alternate opportunities for academic enrichment, students may feel underprepared to seek opportunities in higher education that advance them toward meaningful aspirations and prepare them for their future career pathways.

Because popularity and high grades are not perceived to be as strongly emphasized in the university, students may experience a discontinuity in their understanding of the practices and norms that constitute success. Students who attend a community college before transitioning to the university may also experience a continuity in academic expectations from high school if they perceive that the norms at their community college continue to recognize high grades as the primary metric of academic competence. Reinforcing these expectations in a 
higher education institution may have negative repercussions on student identities if students experience challenges when navigating through new and possibly conflicting cultural norms in the university.

\section{RQ2: Different Figured Worlds of the University Space}

Family's Figured World. Cultural capital and expectations drawn from experiences with family can also have an enduring effect on student expectations, preparation, and overall identity formation in the university (Brooks, 2003; McCarron and Ineklas, 2006; Bryan and Simmons, 2009). The observation that different levels of familial support can function beneficially or detrimentally for students' navigation through higher education has been well established in the literature, especially in studies comparing the experiences of FG and continuing-generation (CG) students (e.g., Terenzini et al.,1996; Bui, 2002; Pike and Kuh, 2005; Engle, 2007). Because the participants in this study were given structured support during their transition to the university, disparities in familial support or how their families may interpret institutional norms may be manifested in the students' identity trajectories in the university. Although this is a transfer student population with an uncommon summer bridge program experience, participants were prompted to articulate how they perceived that their families would define success at the university to examine whether they had similar disparities in their perceived levels of familial support and navigational capital in the university. Consistent with student experiences in previous literature, participants with differences in sociocultural backgrounds configured their figured worlds of family in different ways. Even with a limited and unique data set, the continuity in these experiences validates the potential of our participant sample to provide exemplars of different identity-forming experiences in other academic and sociocultural contexts.

For example, when configuring the figured world of his family into the university space, Yosef believes that his family would define success primarily by his achievement of high grades. However, he claims that they disapprove of his computer science major, because they feel that it does not give him much status in comparison to other culturally prestigious career pathways. Although he believes that this perception of success varies from individual to individual, his own family's metric of success does not appear to overlap at all within his university figured world. This misalignment may be due to differences in educational standards that his family had experienced when they briefly attended (but did not complete) university in another country with potentially different cultural and social norms and values.

They would define it as a 4.0 [GPA] for sure. But I feel like, I honestly don't know because it's very dependent on the family. It's very dependent on what your family expects of you. There's, you know, families that, even when I told my parents that I was going to switch to computer science from being premed, they were extremely shocked, and they didn't like my decision, but they also didn't realize how successful the computer science field is and how, they care about the name that I'm going to make for myself. And, I feel like if they wanted a doctor, they think that, oh, only doctors and lawyers are going to get the high name or engineers and people who do anything else are not going to have as much of it, as much of a status.
Yosef's perception of a conflict between his figured world of his family and his figured world of the university illustrates how his FG status and his cultural background intersect with his lived experiences at the university. His family had different expectations that were likely influenced by limited or different cultural experiences in higher education. However, even with conflicting familial expectations, he was able to navigate toward a more nuanced understanding of university norms after cultivating purposeful experiences in his major.

The perception of the family having a limited understanding of the norms and values of success in the university was common for several of the participants identified as FG. However, CG participants configured their figured worlds of their families in the university space differently. In contrast to Yosef, Cameron's trajectory at the university seems to be strongly influenced by familial expectations. Because both of his parents had received bachelor's degrees, their familiarity with the college experience may be the fundamental reason why their basic metrics of success overlap with his figured world of the university:

Well, I've always grown up in, like, a really strict family where you always need to be at the top of your class, always very high grades. So definitely, if I ever go home and tell them I got like a "B," that's not going to go down very well. So definitely, success is doing well. Getting an "A," you know, even if you get an "A" though, say like a 95 percent in the class, that's great. But could you have done better? If you could have done better, then you should have. That's the way they look at it. And it's a good way to look at it, but it can be like stressful sometimes for sure. Yeah, I mean, to them, really, as long as you're doing well in school grade-wise, because that is what translates to the outside world in the end. How you get a job, how you go on to higher education, right?

This overlap did not appear as strongly (or exist at all) in other program participants who were FG (Table 4). Although many participants de-emphasized the importance of grades when thinking about success at the university, Cameron did not limit his metric of success solely to high grades. He continued to recognize the importance of being proactive in his education and gaining a fundamental understanding of course material so that he could properly apply his content knowledge to his future educational and professional endeavors. Although he perceived that his family's expectations influenced his navigation through the university, the intersection of his family and university figured worlds into the university provided him with the drive and aspiration to continue down a high-achieving and proactive educational pathway.

Several participants described their families as having more limited roles in their university experiences. Maria (FG) stated, "I feel like they don't understand what it means to be at [the university]. They just think it's another university. So, they don't really have high expectations. You know, they just are proud that I'm here studying and graduating." Terrance (CG) also perceived a limited role of his family, but with a different perspective:

I think that they're kind of laid back, and they would just want me to accomplish the goals that I had set. And so, I mean they're incredible. They're very, very proud of the success that I've made and the progress that I have made. But I don't think 
TABLE 4. Contrasting roles of the family

\begin{tabular}{lcc}
\hline Family role & FG & CG \\
\hline Involved & $\begin{array}{c}\text { Family takes a proactive interest in the student's experiences. } \\
\text { However, cultural knowledge and expectations are often } \\
\text { not compatible with university norms. }\end{array}$ & $\begin{array}{c}\text { Family has high expectations for the student's academic } \\
\text { performance because of the firsthand parental experiences } \\
\text { and successes in their own higher education. }\end{array}$ \\
$\begin{array}{c}\text { Family does not take an active role in the student's educational } \\
\text { experiences. They have a limited understanding of what } \\
\text { may constitute success in higher education. }\end{array}$ & $\begin{array}{c}\text { Family does not take an active role, because the student should } \\
\text { independently build experiences without any bias or } \\
\text { influence from parental educational trajectories. }\end{array}$ \\
\hline
\end{tabular}

${ }^{a}$ The involved family role signifies that the family has direct expectations, whereas the hands-off family role implies limited engagement with no specific expectations. Within each family role, parents of FG and CG college students also exhibit differences in their reasons for their engagement or lack thereof.

they have anything specific in mind other than wanting me to accomplish the goals that I want to accomplish.

In contrast to Maria, the partial lack of overlap between Terrance's figured worlds of his family and the university is not attributed to his family's inexperience or misunderstanding of university norms (Table 4). Because both of his parents had completed a college education, their lack of influence on his university figured world is instead due to their desire to see him independently explore his interests and progress toward his goals. He perceives that his family is supporting a space where he can author his identity and cultivate experiences that allow him to proactively pursue his academic interests. His family is providing a nurturing environment where he can independently develop a sense of agency in his educational pursuits, yet he feels that he can still rely on his family as an accessible source of knowledge and guidance as he navigates through the university.

Theme: Contrasting Roles of Family Previous studies have found that FG college students face disadvantages in their transition to higher education because they experience lower levels of familial support and resources in comparison to their CG peers (Terenzini et al., 1996; McConnell, 2000; McCarron and Ineklas, 2006; Engle, 2007). Many FG students feel that their families lack a fundamental understanding of their daily school environment (York-Anderson and Bowman, 1991; Bryan and Simmons, 2009). In the case studies presented, the disparity in the roles of the family between FG and CG students continues to be reinforced. For the FG participants, familial expectations were not well aligned within the students' figured worlds of a successful university student. When asked to define specific familial expectations, many FG participants were not able to easily identify these metrics due to their belief that their families had little understanding of the university experience or how success was achievable in their majors.

In contrast, the CG participants perceived more significant overlap between their university and family figured worlds. Their families were able to empathize and understand the cultural norms of the university due to their own college experiences. For example, Cameron perceived that his parents had rigorous expectations, because they recognized the importance of self-discipline and upholding high standards in higher education and professional career settings. Even in cases in which participants did not perceive any specific expectations from their families, this was due to their perceptions that their families desired for them to build their own experiences and accomplish their personal goals (Table 4). Like in Terrance's case, families of CG students may instead want to provide their children with a space where they can independently develop and pursue their interests with minimal bias or influence from their parents' university experiences. However, unlike FG families, families of CG students could still be an invaluable source of cultural knowledge that students could access for guidance and support as they navigate through the university.

FG participants who did perceive an influence of familial expectations on their trajectory through the university also articulated that the expectations were often broad and did not guide them toward specific practices or resources for achieving their academic goals. For example, Zahra stated, "Family looks at the bigger picture. What are your grades? How well are you doing? Are you going to get accepted to graduate school? Those things." These broad conceptions do not rigidly align with the various norms for achieving success articulated in the students' figured worlds of the university.

Additionally, because several FG participants had parents who did not attend schools in the United States, there is an additional perceived cultural barrier that limits the crossing of the family figured world into the student's figured world of success. As Mateo articulated:

[My family is] not very familiar with the U.S. university system. And for them, they don't know when I'm going to have a midterm or not, or how long is a quarter. And I've been trying to explain to them how the system works. But they always forget, right? It's not their priority.

Although students consistently interact with and interpret the expectations from their families, the cultural knowledge that FG students receive is not necessarily rewarded or capitalized on in traditional higher education settings. Working with incompatible knowledge signifies that FG students may have an additional emotional and cognitive load that they must overcome when reconfiguring their identities in the university community. A misalignment between the family and student figured worlds indicates that many FG students perceive that their families lack a fundamental understanding of the rigorous demands that they face at the university. Many FG students may not have access to a significant source of social capital that guides them toward the opportunities and social networks needed to effectively form a positive identity trajectory in the university. Even with a transfer student population with different backgrounds and an uncommon summer bridge program experience, the conclusions from this analysis are overall consistent with 
previous literature that elucidates a contrast in the levels of familial support between FG and CG students (Pascarella et al., 2004; Collier and Morgan, 2008; Mehta et al., 2011).

University Faculty's Figured World. In the university, participants collectively described several factors that influenced their figured worlds of success in that space, including out of class experiences and building social connections. Faculty were mentioned indirectly when the participants discussed their course work or expanding their interests in their majors, but they did not directly reference faculty expectations as a source of these expanded metrics. Faculty occupy a unique role in the university, because they represent sources of social and cultural capital in their respective fields and are therefore significant actors in the same space where students construct their academic identities and career aspirations (Pascarella and Terenzini, 2005; Kim and Sax, 2009). Furthermore, recognition from faculty serves as substantial identify-forming events (Carlone and Johnson, 2007).

Despite participating in a research-based summer bridge program and having mentored research experiences, most of the students did not discuss faculty expectations outside the classroom setting. Within this more traditional academic context, many participants struggled to identify specific and well-defined metrics when articulating how they perceived faculty would define success. For example, Terrance articulates that there is not a comprehensive conception of success among all the faculty departments within the university. Because of this variation, his figured world of university faculty fails to completely overlap with the metrics of success he defined within his university figured world.

I think that's going to vary pretty widely, wildly. I think that the [university] departments are so large that there is not a cohesive vision as to what makes success. And if there is a cohesive vision, I don't think that most professors know it or follow it when evaluating students.

Similarly, Mona found it difficult to identify metrics of success among faculty. However, she assumes that faculty expectations show at least some overlap with her figured world of the university. She claims that developing passion and a genuine interest in the subject matter of one's major is a metric of success that is likely to be recognized and respected by university faculty.

In all honesty, I mean, I really haven't asked faculty yet [laughs]. So, I'm not really sure, but if I had to guess, it's definitely a student who goes to office hours all the time, gets "A's" on exams, is genuinely interested in the subject matter. That kind of student definitely gets recognized by the professor. ... So the success measured by a professor, I would probably say is the ability to connect and convey the same ideas [in the class] can go a little bit beyond that.

Although Mona states that she has not directly had conversations with faculty regarding their expectations and values, she indicates that there are underlying cues that have at least partially molded her understanding of the practices that faculty may perceive as successful. Even without one-on-one interac- tion, faculty are conveying verbal and nonverbal cues that intentionally or unintentionally establish expectations that students may adopt, negotiate, or resist when constructing their own figured worlds of the university.

The perceived variability in faculty expectations prevented several participants from uniformly configuring their figured worlds of faculty within their own figured worlds of a successful university student. Cameron articulates that there may be multiple extremes that lie on a continuum of how faculty define and measure success. For example, he perceives that some faculty may emphasize grades. Conversely, he also recognizes that other faculty may shift away from the emphasis of grades and instead encourage a fundamental understanding of course material that facilitates critical thinking and application of academic knowledge.

I think it depends on the professor. I think a lot of professors are very grade based also, and if you can do well on their exam, then they think you're a successful student. But everyone has very different exams, right? So, [I'm] taking classes where there are just three problems on the exam, and you have to know the concepts. I'm also taking exams and classes where it's just straight up, just, did you memorize, like, the lecture, right? You don't really have to do any application [of] critical thinking. It's just straight up, like, did you listen? Did you come to class? So, it's kind of hard to say what exactly they define success, because I think their ideas are so different. So yeah, it's tough to say. But I would, I would hope we kind of shift more toward what I said earlier, which is if you understand the material well enough to teach it, and if you can apply it to different, to different scenarios, right? Not just, like, draw an amino acid structure. Like, anyone can do that.

Although most participants did not mention faculty specifically in a mentored research setting, some alluded to expectations that extended beyond the traditional classroom setting. For Maria, university faculty's definition of success would include well-roundedness in other social issues beyond one's major. She also articulates that students who are proactive and cultivate meaningful connections outside the university are recognized by faculty as being successful:

It's so hard, so many things. So, [it] would be [being] disciplined for sure. And like I said, they would be aware of other issues going on, not just, you know, what you're studying. Someone who is willing to just go outside their comfort zone and, you know, go talk to people whenever you have a question, like not be afraid to get it answered. And someone who sees just beyond [the university].

Theme: Variable Metrics of Success among Faculty. All participants in this study were provided with opportunities as part of the summer bridge program to network with faculty in STEM. Because students take general education courses, nonSTEM faculty may also have expectations that could influence how STEM students construct their figured worlds of success. The interview protocol referred to faculty expectations without prompting participants to discuss STEM faculty specifically, and the broad scope of this interview question allowed the participants to comprehensively describe the faculty expectations they 
felt were most salient in the university. Most participants described success in a traditional classroom setting rather than in a mentored research setting.

When prompted to elaborate on what they perceived as behaviors recognized by faculty as being successful, many participants indicated at least some overlapping metrics between their figured worlds of faculty and their figured worlds of the university. These metrics included but were not limited to 1) building relevant connections and practical experiences, 2) engaging proactively in classroom discourses and activities, and 3) focusing on long-term contributions to research or other extracurricular opportunities in their fields of study. Although the participants were able to identify overlap between these figured worlds, they also perceived variability in how individual faculty members and different departments defined success. As noted by Terrance, the university departments are so large that it is difficult to establish "a cohesive vision as to what makes success." This perception of variability is also evident in recognition of different extremes as to how faculty define success. These extremes could range from measuring success exclusively by academic performance to students making significant contributions in research and other professional settings. For example, Mateo articulated:

I think the minimum [expectation] is to do well in class. The other one is to contribute to the class, bring in other subjects that could relate to a class. Probably do some of their research in their lab, and if they find something interesting, [a professor will think], "Not only [are you] doing well in my class, but you're actually writing something [for] my lab. Probably that will be the extreme side of professors of success, but in general I think professors think that a good student doing well in their classes is the success that they expect.

We recognize that the participants in this study represent a small sample of transfer students who received guidance in their transition to the university through a summer bridge program. The program connected participants to faculty and provided them with resources that would initiate research experiences in STEM. The common summer bridge program experience may have converged participants' figured worlds of success. However, even with resources that supported them to overcome the institutional barrier of approaching and connecting with faculty, many participants still did not recognize a cohesive vision of success based on their interpretations of faculty expectations. Because students draw from multiple experiences and interactions when constructing their figured worlds of success in the university, it is not surprising that many participants did not articulate complete alignment between faculty expectations and their own figured worlds of success in the university.

The program faculty continued to provide participants with social and networking opportunities after the summer, and most participants carried out independent research projects in a faculty's laboratory following the program. Therefore, the participants were more likely to have interacted with faculty compared with other students without these supports. Even without one-on-one discussions with faculty, the participants' figured worlds of how university faculty define success still represents their lived realities. Regardless of whether there is a cohesive vision of success among faculty that is not perceived by students, the students' perception of faculty values is ultimately going to affect how they position their understanding of the norms of success in their figured worlds of the university.

The variable overlap between the student and faculty figured worlds elicits concerns regarding power and privilege. Barriers to understanding faculty expectations may include generational, cultural, or social class differences between students and faculty (Dika, 2012). Studies of non-transfer students have found racial differences in students' propensity for interacting with faculty, and some of these studies have observed that students from minoritized groups engage in fewer faculty interactions (Cole, 2007; Hurtado et al., 2011). For example, racially and ethnically minoritized students have reported that faculty held stereotypes regarding their academic competence that influenced the quantity and quality of their subsequent interactions (Carlone and Johnson, 2007; Chang et al., 2011; Beasley and Fischer, 2012). Similarly, because the cultural capital that FG students have from their families is often not transferable to a higher education institution, FG students have reported experiencing greater challenges in fulfilling faculty expectations when navigating and managing course work than their CG counterparts (Collier and Morgan, 2008).

Transfer student populations typically encompass these minoritized identities, and transfer students are unique in that they experience multiple institutional cultures in higher education. Because community college courses are smaller compared with those at large research universities, transfer students may be accustomed to an institutional culture in which faculty may be more accessible, which could lead to transfer shock during their initial navigation of the university (Hills, 1965; Townsend and Wilson, 2006; Laanan et al., 2010; Chrystal et al., 2013). Furthermore, while the stereotypical experiences of minoritized identities described earlier were not directly referenced in the participants' figured worlds of faculty, the potential biases from faculty documented elsewhere (e.g., Carlone and Johnson, 2007; Shaw et al., 2019) may have also contributed to the variability in faculty expectations becoming more salient.

Interactions with faculty are crucial for cultivating experiences and opportunities at the university, so the perception of inconsistent faculty expectations may be an additional challenge that transfer students face when they are not afforded access to the resources that positively guide their identity trajectories in the university. Faculty have the credibility and power to recognize students as being competent, and students rely on faculty as a resource to understand and navigate through the institutional norms of the university (Carlone and Johnson, 2007). For students to shape a positive identity trajectory that allows them to fulfill their academic and professional goals, they must be provided with a space to process their experiences and feel recognized for their achievements (Carlone and Johnson, 2007). However, students who experience negative discourses with faculty or perceive that they are not fulfilling faculty expectations are not thriving in a space where they can author strong identities in the university community (Roksa and Whitley, 2017). This lack of motivation can be further exacerbated if there is a disparity between university faculty expectations and what students perceive those expectations to be (Collier and Morgan, 2008). A lack of overlap between the faculty and university figured worlds could potentially dissuade transfer students from approaching faculty and pursuing 
professional opportunities, especially in the STEM community (Bangera and Brownell, 2014).

\section{Limitations and Future Directions}

There are several limitations to this study. First, our study sample represents transfer students from a summer bridge program that provided mentorship experiences and resources. We acknowledge that this form of structured guidance is not typically accessible to most community college students who transfer to a university. These students were also selected for admission into the program in part by their academic merit in community college and a recommendation from a science instructor who could advocate their potential for research. These students may have had considerably more successes earlier in their educational trajectories than a typical community college student transferring to a university. While the experiences articulated by our participants are not broadly generalizable, the results were intended to illustrate a range of experiences and the potential ways in which students could configure their identities in different educational spaces. Through the summer bridge program, participants were provided with activities that supported their transition to the university, and these resources may have influenced or narrowed how they constructed their figured worlds of success. The participants in this study articulated unique definitions that were personally meaningful to their academic and professional trajectories. It is possible that a broader sample of students would have different definitions of success at the university based on their individual experiences.

Second, the participants collectively attended different community colleges and high schools. Each of these institutions likely had a culture that led to unique identity-forming experiences and expectations for different participants. The metrics of success defined in the participants' figured worlds of high school may be different from students who transitioned directly from a high school to a university. The participants' figured worlds of high school were included to examine a range of identity-forming events and experiences along the continuum of their educational trajectories. Transfer students are a unique population who experience an additional institutional culture on their trajectories toward the university, and the institutional cultural norms in community college may reinforce or counter the norms experienced in high school. This additional transition adds another layer of identity-forming experiences that can ultimately affect how transfer students navigate through the university, especially if there are continuities in their interpretations of norms across the high school and community college learning environments that do not align with the university. Therefore, the experiences described in the participants' figured worlds of high school and university should not be generalized to students who directly attend a 4-year university out of high school.

Third, the figured worlds of the family and faculty were triangulated within the university space, even though we did not directly interview family or faculty. Success within these figured worlds is based on how the participants perceived their families and faculty would define success and do not necessarily reflect how success may be defined by these individuals. However, using this perceived understanding remains advantageous for examining the cultural and social capital that transfer students consider available to them. Although this was a transfer student sample with an uncommon summer bridge program experience, the participants' figured worlds of their families were consistent with previous literature that highlights disparities in perceived levels of familial support between FG and CG students. Observing stereotypical experiences in this figured world validated the credibility of the participants to relate other identity-forming experiences that could potentially be manifested in the transition from community college to university.

Finally, each participant's articulation of success in community college and high school relied on retrospective reflection. Future longitudinal studies could provide more systematic comparisons of how students define success during their lived experiences in each educational space. In situ descriptions of the community college and high school figured worlds would serve as a more structured basis for examining how students redefine their understanding of institutional norms as they navigate across different academic settings.

Future research should focus on additional interpersonal interactions and experiences that influence how transfer students' author their identities in the university. For example, the interview protocol could prompt students to articulate how they perceive their peers would define success. Peers are actors in the same space where individual students interpret sociocultural norms and map their identity trajectories in relation to these norms. Interactions with peers play a significant role in how students develop a social and professional network, navigate through cultural norms, and cultivate an overall sense of community in the university (Maunder, 2018); therefore, peer relations may cultivate different academic and social expectations that influence how transfer students configure their identities in their educational trajectories.

Another dimension of the figured worlds framework that could be addressed in greater depth is power structures. Newcomers who enter a figured world exercise their agency based on their acceptance or resistance to the norms and values established by individuals in power (Langer-Osuna, 2015). Various theoretical frameworks can reveal how privilege and power structures affect the educational and cultural worlds that individuals navigate across time (Esmonde and Booker, 2016). Identities are ultimately authored as individuals experience sociocultural (e.g., race, ethnicity, gender, financial, etc.) divisions and position themselves in relation to the various discourses and practices that they are exposed to (Ladson-Billings and Tate, 1995; Barron, 2014). A future interview protocol should prompt students to reflect on institutional norms with respect to policies and power structures sustained by faculty and administrators. Exploring this additional dimension of the figured worlds framework would contribute to an understanding of how transfer students position themselves in relation to power structures that may enable or constrain their identities as they navigate across different institutional contexts (Esmonde and Langer-Osuna, 2013).

Future studies could also focus on other sociocultural dimensions of identity in greater depth. Although our study population was diverse in terms of race and gender, few students directly articulated how their sociocultural identities impacted their academic and social experiences. Many students may have a racialized and/or gendered experience based on the cultural and dominant narratives that are associated with that identity. 
TABLE 5. Summary of themes and implications ${ }^{a}$

\begin{tabular}{|c|c|}
\hline Themes & Implications \\
\hline $\begin{array}{l}\text { - Grades are not everything: Students report the importance of } \\
\text { research experiences and professional connections in the university, } \\
\text { in contrast to an emphasis on high grades in community college } \\
\text { and high school } \\
\text { - Contrasting roles of family: Cultural knowledge of FG students is } \\
\text { not necessarily recognized in traditional higher education settings } \\
\text { - Variable metrics of success among faculty: Students perceive high } \\
\text { variability in how individual faculty and different departments } \\
\text { defined success in the university }\end{array}$ & $\begin{array}{l}\text { - More university partnerships with community colleges to support } \\
\text { transfer students' entry into research and professional programs } \\
\text { - Increased access to mentorship opportunities with faculty in the } \\
\text { initial transition to the university } \\
\text { - Access to advising that introduces students to resources before the } \\
\text { transition to university } \\
\text { - An improved collaborative network of support between STEM faculty } \\
\text { and professional advising that increases access to meaningful } \\
\text { advising and mentorship experiences for prospective transfer } \\
\text { students }\end{array}$ \\
\hline
\end{tabular}

The themes emerging from our data have several implications for institutional practices and interventions relating to partnerships, mentoring, and advising.

For example, students who are women of color in STEM may be impacted by unconscious biases in their discourses with individuals in power (Carlone and Johnson, 2007; Castro and Collins, 2021). Identifying differences in experiences across different races and genders could reveal additional psychosocial and cultural dimensions of identity that affect students' academic expectations and navigational processes across institutional norms (Gloria and Rodriguez, 2000). Additionally, applying frameworks that examine the cultural wealth that students draw from their families and home communities could provide a broader lens into how students' sociocultural identities can positively or negatively influence their navigation through different educational spaces (Yosso, 2005).

\section{Implications}

The figured worlds framework enhances our understanding of how individual transfer students navigate their identities across different educational spaces. This study also highlights the potential challenges that transfer students face as they reconfigure their own understanding of academic and social norms during their transitions to university. The themes emerging from our data have several implications for institutional practices and interventions (Table 5).

Many participants articulated high grades as the primary metric of success in their figured worlds of community college. High grades represent a tangible extrinsic reward that students perceive as a fulfillment of expectations and a demonstration of competence (Spady, 1970; Hurtado et al., 2007). However, the emphasis on high grades coupled with the perceived lack of meaningful academic and research experiences in community college could have implications on how students choose to build their identities in the university. For example, students may be less inclined to seek out research and professional opportunities available at the university. Without these practical experiences, students may be deprived of a foundational lens into what a career in STEM would entail.

Transfer students face the institutional barrier of having less time to reconfigure their figured worlds of success once they transfer to university, and most students are not provided with structured resources to navigate this transition. Non-transfer students have more time to accumulate experiences and seek lasting connections. The inherent inequity in the time to navigate university norms could have repercussions for transfer student outcomes and success in STEM. If transfer students only begin to view success beyond grades after they transfer, the disadvantage in time to navigate their new institutional envi- ronment and build long-term connections and experiences in their major could lead to disparities in preparation for the job market or graduate and professional studies. Because transfer student populations are disproportionately from minoritized backgrounds, the additional time constraints for accumulating connections and experiences is detrimental for promoting broader participation in STEM majors and careers. It is essential for institutions to recognize these inherent inequities and to support initiatives that stabilize the transition while providing sufficient resources to facilitate a timely enculturation of transfer students into the university community (Tobolowsky and Cox, 2012; Starobin et al., 2016).

Participants articulated that the emphasis on high grades was challenged by participating in mentored research experiences in STEM. Practical and mentored experiences had shifted participants' figured worlds of the university toward a more nuanced understanding of success. The pursuit of STEM degrees involves the transition into a professional learning community with potentially unfamiliar norms and values (Bangera and Brownell, 2014; Spronken-Smith et al., 2014). Transfer students who were not previously exposed to the importance of participating in academic experiences beyond the classroom may not have access to opportunities that develop the intrinsic motivation and aspiration to persist in STEM (Wenger, 1998; Hirst et al., 2014). Research and other professional opportunities should be made accessible to transfer students to develop a sense of agency in the university community and to cultivate professional skills.

To make these opportunities available, universities could partner with community colleges to recruit transfer students into programs that promote early inclusion in the STEM community (Hirst et al., 2014). Initiating faculty interactions early in the university experience is essential, as students majoring in STEM will need to approach and interact with faculty to gain access to research and professional opportunities. Faculty are important actors in the university community of practice who have access to the resources and cultural knowledge that students rely on when navigating through potentially unfamiliar cultural norms in the university and STEM communities (Wenger, 1998). Students who are newcomers to the university depend on clear faculty expectations to construct their individual figured worlds of success. However, a misunderstanding of faculty expectations or a perception that faculty are unapproachable could potentially dissuade students from seeking the faculty interactions that are essential for cultivating mentored experiences. Conversely, positive interactions between students 
and faculty have been shown to increase student academic achievement, engagement, and motivation (Volkwein et al., 1986; Lau, 2003; Pascarella and Terenzini, 2005; Kim and Sax, 2009; Hurtado et al., 2011; Hoffman, 2014). Students who perceive faculty as being approachable and readily accessible are more likely to use them as a resource in their long-term academic and career goals (Volkwein et al., 1986; Laanan, 2007).

Support programs under the guidance of faculty may be the ultimate bridge for helping transfer students redefine their understanding of success in the university. Although participants in this study articulated variation in how they perceived faculty would define success, many recognized at least partial alignment of perceived faculty expectations and their own evolved understandings of university norms. Interacting with a variety of faculty mentors in the initial transition to the university may provide transfer students with multiple perspectives on how to achieve success. Students rely on a clear understanding of sociocultural patterns and behaviors that are recognized by faculty as a demonstration of competence and strong performance in the university (Carlone and Johnson, 2007). For students who are accustomed to defining success primarily by high grades in community college, faculty guidance in the initial transition to the university may result in earlier recognition of the importance of practical and proactive experiences in their STEM majors. Institutional support programs that facilitate these faculty interactions and transitional resources are especially important for FG students. As presented in this study, several FG students perceived that their families were unable to provide practical guidance due to their lack of familiarity with the university system. These students may not have access to an essential form of navigational capital that can help them become enculturated into the university community (Townsend and Wilson, 2006; Townsend, 2008). Introducing transfer students to faculty who are interested in their long-term academic goals could help them develop a sense of community and belonging that supports a positive and robust identity production in the university (Johnson et al., 2007; Townley et al., 2013). Because identity production is a complex process, it is not practical for academic institutions to adopt "one size fits all" approaches for interventions and resources. However, faculty and administrators are obligated to create and sustain inclusive spaces where students can individually construct meaningful experiences and discourses. Faculty must be mindful of their values and the expectations that they are conveying, as discourses with students can have enduring effects on how students interpret institutional norms and socially construct their identities.

Stabilizing the transition into the university may also be achievable through increased access to purposeful and constructive advising in community college. Advisors in community college can serve as a fundamental source of social capital that introduces resources to students before their prospective academic transition. These advisors can be official advising staff or trusted faculty members who informally provide advice on how to successfully transition into the university. However, encouraging student progression in STEM requires that advisors be knowledgeable about disciplinary STEM major requirements and resources that offer professional development and research opportunities (Packard and Jeffers, 2013). An improved collaborative network of support between STEM faculty and professional advising could provide multiple perspectives and resources that facilitate increased access to meaningful advising and mentorship experiences for prospective transfer students.

In summary, although community colleges are a preliminary academic home for a large and diverse population of undergraduate students pursuing STEM, few studies have examined the identity negotiation that transfer students experience in their transition to the university. This qualitative analysis highlighted the variations in how a group of transfer students pursuing STEM individually assigned meaning to their social and academic experiences at the university. Expectations and understandings of university norms were based on the perceived influence of their families, university faculty, and their previous academic experiences in community college and high school. This analysis informs practices that university and community college personnel can implement to foster a stabilized academic transition for transfer students; these practices should include increased access to mentorship and professional opportunities for transfer students during the community college to university transition. These experiences can provide transfer students with the space and resources needed to construct a positive identity trajectory and achieve a sense of meaning and belonging in their pursuit of a STEM degree.

\section{ACKNOWLEDGMENTS}

We are grateful to all the study participants for sharing their experiences and perspectives and to E. Macagno for help in recruiting participants. The summer bridge program was supported by the National Science Foundation under grant no. 1355045 and the Division of Biological Sciences at the University of California San Diego. We thank L. Warnock for conducting the pilot set of interviews and F. Contreras, E. Macagno, and members of the discipline-based education research journal club for feedback on the article. Research in this publication was supported in part by an award from the Academic Senate Grant Funding Programs for General Campus Research at the University of California San Diego (award no. 058396) and by the National Eye Institute and National Institute of Neurological Disorders and Stroke of the National Institutes of Health under award no. R25NS119707. The content is solely the responsibility of the authors and does not necessarily represent the official views of the National Institutes of Health or the National Science Foundation. The authors declare no conflict of interest.

\section{REFERENCES}

Aldiabat, K. M., \& Le Navenec, C. L. (2018). Data saturation: The mysterious step in grounded theory methodology. Qualitative Report, 23(1), 245261.

Anderson, E., \& Kim, D. (2006). Increasing the success of minority students in science and technology. Washington, DC: American Council on Education.

Asai, D. J. (2020). Race matters. Cell, 181(4), 754-757.

Azmitia, M., Syed, M., \& Radmacher, K. (2013). Finding your niche: Identity and emotional support in emerging adults' adjustment to the transition to college. Journal of Research on Adolescence, 23(4), 744-761.

Bahr, P. R., Toth, C., Thirolf, K., \& Massé, J. C. (2013). A review and critique of the literature on community college students' transition processes and outcomes in four-year institutions. In Paulsen, M. B. (Ed.), Higher education: Handbook of theory and research (pp. 459-511). New York: Springer.

Bangera, G., \& Brownell, S. E. (2014). Course-based undergraduate research experiences can make scientific research more inclusive. CBE-Life Sciences Education, 13(4), 602-606. 
Barron, I. (2014). Finding a voice: A figured worlds approach to theorising young children's identities. Journal of Early Childhood Research, 12(3), 251-263.

Beasley, M. A., \& Fischer, M. J. (2012). Why they leave: The impact of stereotype threat on the attrition of women and minorities from science, math and engineering majors. Social Psychology of Education, 15(4), 427-448.

Benitez, M., Jr. (2010). Resituating culture centers within a social justice framework: Is there room for examining Whiteness? In Patton, L. D. (Ed.), Culture centers in higher education: Perspectives on identity, theory, and practice (pp. 119-134). Sterling, VA: Stylus.

Berzonsky, M. D., \& Kuk, L. S. (2000). Identity status, identity processing style, and the transition to university. Journal of Adolescent Research, 15(1) 81-98.

Biza, I., Jaworski, B., \& Hemmi, K. (2014). Communities in university mathematics. Research in Mathematics Education, 16(2), 161-176.

Bourdieu, P. (1977). Cultural reproduction and social reproduction. In Karabel, J. \& Halsey, A. H. (Eds.), Power and ideology in education (pp. 487511). New York: Oxford University Press.

Bourdieu, P. (1997). The forms of capital. In Halsey, A. H., Lauder, H., Brown P., \& Stuart Wells, A. (Eds.), Education: Culture, economy, society (pp. 46-58). Oxford: Oxford University Press.

Bourdieu, P., \& Passeron, J-C. (1990). Reproduction in education, society and culture. (Vol. 4). London: Sage.

Brickhouse, N. W. (2000). Embodying science: A feminist perspective on learning. Journal of Research in Science Teaching, 38(3), 282-295

Brooks, R. (2003). Young people's higher education choices: The role of family and friends. British Journal of Sociology of Education, 24(3), 283297.

Bryan, E., \& Simmons, L. A. (2009). Family involvement: Impacts on post-secondary educational success for first-generation Appalachian college students. Journal of College Student Development, 50(4), 391-406.

Bui, K. V. T. (2002). First-generation college students at a four-year university: Background characteristics, reasons for pursuing higher education, and first-year experiences. College Student Journal, 36(1), 3-12.

Calabrese Barton, A., Kang, H., Tan, E., O'Neill, T. B., Bautista-Guerra, J., \& Brecklin, C. (2013). Crafting a future in science: Tracing middle school girls' identity work over time and space. American Educational Research Journal, 50(1), 37-75.

Calabrese Barton, A., \& Tan, E. (2010). We be burnin'! Agency, identity, and science learning. Journal of the Learning Sciences, 19(2), 187-229.

Calabrese Barton, A., \& Tan, E. (2019). Designing for rightful presence in STEM: The role of making present practices. Journal of the Learning Sciences, 28(4-5), 616-658.

Calabrese Barton, A., \& Tan, E. (2020). Beyond equity as inclusion: A framework of "rightful presence" for guiding justice-oriented studies in teaching and learning. Educational Researcher, 49(6), 433-440.

Caraballo, L. (2019). Being "loud": Identities-in-practice in a figured world of achievement. American Educational Research Journal, 56(4), 1281-1317.

Carlone, H. B., \& Johnson, A. (2007). Understanding the science experiences of successful women of color: Science identity as an analytic lens. Journal of Research in Science, 44(8), 1187-1218.

Case, A. D., \& Hunter, C. D. (2012). Counterspaces: A unit of analysis for understanding the role of settings in marginalized individuals' adaptive responses to oppression. American Journal of Community Psychology, 50(1-2), 257-270

Castro, A. R., \& Collins, C. S. (2021). Asian American women in STEM in the lab with "White men named John." Science Education, 105(1), 33-61.

Chaffee, R., \& Gupta, P. (2018). Accessing the elite figured world of science. Cultural Studies of Science Education, 13(3), 797-805.

Chang, A. (2014). Identity production in figured worlds: How some multiracial students become racial atravesados/as. Urban Review, 46(1), 25-46.

Chang, M. J., Eagan, M. K., Lin, M. H., \& Hurtado, S. (2011). Considering the impact of racial stigmas and science identity: Persistence among biomedical and behavioral science aspirants. Journal of Higher Education 82(5), 564-596

Cherng, H. Y. S., Calarco, J. M., \& Kao, G. (2013). Along for the ride: Best friends' resources and adolescents' college completion. American Educational Research Journal, 50(1), 76-106.
Chin-Newman, C. S., \& Shaw, S. T. (2013). The anxiety of change: How new transfer students overcome challenges. Journal of College Admission, 221, 14-21.

Chrystal, L. L., Gansemer-Topf, A., \& Laanan, F. S. (2013). Assessing students transition from community college to a four-year institution. Journal of Assessment and Institutional Effectiveness, 3(1), 1-18.

Cohen, A. M., Brawer, F. B., \& Kisker, C. B. (2014). The American community college (6th ed.). San Francisco: Jossey-Bass.

Cohen, J. (1960). A coefficient of agreement for nominal scales. Educational and Psychological Measurement, 20(1), 37-46.

Cole, D. (2007). Do interracial interactions matter? An examination of student-faculty contact and intellectual self-concept. Journal of Higher Education, 78(3), 249-281.

Collier, P. J., \& Morgan, D. L. (2008). "Is that paper really due today?": Differences in first-generation and traditional college students' understandings of faculty expectations. Higher Education, 55(4), 425-446.

Corbin, J., \& Strauss, A. (2015). Basics of qualitative research: Techniques and procedures for developing grounded theory. Thousand Oaks, CA: Sage.

Costa, V. B. (1995). When science is "another world": Relationships between worlds of family, friends, school, and science. Science Education, 79(3), $313-333$.

Cribbs, J. D., Hazari, Z., Sonnert, G., \& Sadler, P. M. (2015). Establishing an explanatory model for mathematics identity. Child Development, 86(4), 1048-1062.

Crisp, G., \& Nuñez, A. M. (2014). Understanding the racial transfer gap: Modeling underrepresented minority and nonminority students' pathways from two- to four-year institutions. Review of Higher Education, 37(3), $291-320$.

Dika, S. L. (2012). Relations with faculty as social capital for college students: Evidence from Puerto Rico. Journal of College Student Development 53(4), 596-610.

Dika, S. L., \& D'Amico, M. M. (2016). Early experiences and integration in the persistence of first-generation college students in STEM and non-STEM majors. Journal of Research in Science Teaching, 53(3), 368-383.

diSessa, A. A. (2007). An interactional analysis of clinical interviewing. Cognition and Instruction, 25(4), 523-565.

Edgerton, J. D., \& Roberts, L. W. (2014). Cultural capital or habitus? Bourdieu and beyond in the explanation of enduring educational inequality. Theory and Research in Education, 12(2), 193-220.

Engle, J. (2007). Postsecondary access and success for first-generation college students. American Academic, 3(1), 25-48.

Esmonde, I., \& Booker, A. N. (2016). Power and privilege in the learning sciences: Critical and sociocultural theories of learning. New York: Routledge.

Esmonde, I., \& Langer-Osuna, J. M. (2013). Power in numbers: Student participation in mathematical discussions in heterogeneous spaces. Journal for Research in Mathematics Education, 44(1), 288-315.

Ethier, K. A., \& Deaux, K. (1994). Negotiating social identity when contexts change: Maintaining identification and responding to threat. Journal of Personality and Social Psychology, 67(2), 243-251.

Farnsworth, V., Kleanthous, I., \& Wenger-Trayner, E. (2016). Communities of practice as a social theory of learning: A conversation with Etienne Wenger. British Journal of Educational Studies, 64(2), 139-160.

Flaga, C. T. (2006). The process of transition for community college transfer students. Community College Journal of Research and Practice, 30(1) 3-19.

Flyvbjerg, B. (2006). Five misunderstandings about case-study research Qualitative Inquiry, 12(2), 219-245.

Gee, J. P. (2000). Chapter 3: Identity as an analytic lens for research in education. Review of Research in Education, 25(1), 99-125.

Gloria, A. M., \& Rodriguez, E. R. (2000). Counseling Latino university students: Psychosociocultural issues for consideration. Journal of Counseling \& Development, 78(2), 145-154.

Godwin, A., Potvin, G., Hazari, Z., \& Lock, R. (2016). Identity, critical agency, and engineering: An affective model for predicting engineering as a career choice. Journal of Engineering Education, 105(2), 312-340.

Graham, M. J., Frederick, J., Byars-Winston, A., Hunter, A. B., \& Handelsman, J. (2013). Increasing persistence of college students in STEM. Science, 341(6153), 1455-1456. 
Hagedorn, L. S., Cypers, S., \& Lester, J. (2008). Looking in the review mirror: Factors affecting transfer for urban community college students. Community College Journal of Research and Practice, 32(9), 643-664.

Hagedorn, L. S., \& Purnamasari, A. V. (2012). A realistic look at STEM and the role of community colleges. Community College Review, 40(2), 145164.

Handley, K., Sturdy, A., Fincham, R., \& Clark, T. (2006). Within and beyond communities of practice: Making sense of learning through participation, identity and practice. Journal of Management Studies, 43(3), 641653.

Harper, S. R. (2013). Am I my brother's teacher? Black undergraduates, racial socialization, and peer pedagogies in predominantly white postsecondary contexts. Review of Research in Education, 37(1), 183-211.

Harrison, C., \& Tanner, K. D. (2018). Language matters: Considering microaggressions in science. CBE-Life Sciences Education, 17(1), fe4.

Hazari, Z., Sadler, P. M., \& Sonnert, G. (2013). The science identity of college students: Exploring the intersection of gender, race, and ethnicity. Journal of College Science Teaching, 42(5), 82-91.

Hazari, Z., Sonnert, G., Sadler, P. M., \& Shanahan, M. C. (2010). Connecting high school physics experiences, outcome expectations, physics identity, and physics career choice: A gender study. Journal of Research in Science Teaching, 47(8), 978-1003.

Hennink, M. M., Kaiser, B. N., \& Marconi, V. C. (2017). Code saturation versus meaning saturation: How many interviews are enough? Qualitative Health Research, 27(4), 591-608.

Hills, J. R. (1965). Transfer shock: The academic performance of the junior college transfer. Journal of Experimental Education, 33(3), 201-215.

Hirst, R. A., Bolduc, G., Liotta, L., \& Packard, B. W. L. (2014). Cultivating the STEM transfer pathway and capacity for research: A partnership between a community college and a 4-year college. Journal of College Science Teaching, 43(4), 12-17.

Hoffman, E. M. (2014). Faculty and student relationships: Context matters. College Teaching, 62(1), 13-19.

Holland, D., Lachiotte, W., Skinner, D., \& Cain, C. (1998). Identity and agency in cultural worlds. Cambridge MA: Harvard University Press.

Holland, D., \& Lave, J. (2009). Social practice theory and the historical production of persons. Actio: An International Journal of Human Activity Theory, 2(1), 1-15

Holmegaard, H. T., Madsen, L. M., \& Ulriksen, L. (2014). A journey of negotiation and belonging: Understanding students' transitions to science and engineering in higher education. Cultural Studies of Science Education 9(3), 755-786.

Hosbein, K. N., \& Barbera, J. (2020). Development and evaluation of novel science and chemistry identity measures. Chemistry Education Research and Practice, 21(3), 852-877.

Hurtado, S., Eagan, M. K., Tran, M. C., Newman, C. B., Chang, M. J., \& Velasco, P. (2011). "We do science here": Underrepresented students' interactions with faculty in different college contexts. Journal of Social Issues, 67(3), 553-579.

Hurtado, S., Han, J. C., Sáenz, V. B., Espinosa, L. L., Cabrera, N. L., \& Cerna O. S. (2007). Predicting transition and adjustment to college: Biomedical and behavioral science aspirants' and minority students' first year of college. Research in Higher Education, 48(7), 841-887.

Jackson, D. L., Stebleton, M. J., \& Laanan, F. S. (2013). The experience of community college faculty involved in a learning community program. Community College Review, 41(1), 3-19.

Jackson, P. A., \& Seiler, G. (2013). Science identity trajectories of latecomers to science in college. Journal of Research in Science Teaching, 50(7), 826-857.

Johnson, D. R., Soldner, M., Leonard, J. B., Alvarez, P., Inkelas, K. K., Rowan-Kenyon, H. T., \& Longerbeam, S. D. (2007). Examining sense of belonging among first-year undergraduates from different racial/ethnic groups. Journal of College Student Development, 48(5), 525-542.

Jurow, A. S. (2005). Shifting engagements in figured worlds: Middle school mathematics students' participation in an architectural design project. Journal of the Learning Sciences, 14(1), 35-67.

Kahu, E., Stephens, C., Leach, L., \& Zepke, N. (2015). Linking academic emotions and student engagement: Mature-aged distance students transition to university. Journal of Further and Higher Education, 39(4), 481-497.

Kanim, S., \& Cid, X. C. (2020). Demographics of physics education research. Physical Review Physics Education Research, 16(2), 020106.

Kim, Y. K., \& Sax, L. J. (2009). Student-faculty interaction in research universities: Differences by student gender, race, social class, and first-generation status. Research in Higher Education, 50(5), 437-459.

Laanan, F. S. (2007). Studying transfer students: Part II: Dimensions of transfer students' adjustment. Community College Journal of Research and Practice, 31(1), 37-59.

Laanan, F. S., Starobin, S. S., \& Eggleston, L. E. (2010). Adjustment of community college students at a four-year university: Role and relevance of transfer student capital for student retention. Journal of College Student Retention: Research, Theory \& Practice, 12(2), 175-209.

Ladson-Billings, G., \& Tate, W. (1995). Toward a critical race theory of education, Teachers College Record, 97(1), 47-68.

Lakin, J. M., \& Elliott, D. C. (2016). STEMing the shock: Examining transfer shock and its impact on STEM major and enrollment persistence. Journal of the First-Year Experience \& Students in Transition, 28(2), 9-31.

Landis, J. R., \& Koch, G. G. (1977). The measurement of observer agreement for categorical data. Biometrics, 33(1), 159-174.

Langer-Osuna, J. M. (2015). From getting "fired" to becoming a collaborator: A case of the coconstruction of identity and engagement in a project-based mathematics classroom. Journal of the Learning Sciences, 24(1), 53-92.

Lau, L. K. (2003). Institutional factors affecting student retention. Education, 124(1), 126-136

Lave, J., \& Wenger, E. (1991). Situated learning: Legitimate peripheral participation. Cambridge: Cambridge University Press.

Le, P. T., Doughty, L., Thompson, A. N., \& Hartley, L. M. (2019). Investigating undergraduate biology students' science identity production. CBE-Life Sciences Education, 18(4), ar50.

Lo, S. M., Gardner, G. E., Reid, J., Napoleon-Fanis, V., Carroll, P., Smith, E., \& Sato, B. K. (2019). Prevailing questions and methodologies in biology ed ucation research: A longitudinal analysis of research in CBE-Life Sciences Education and at the Society for the Advancement of Biology Education Research. CBE-Life Sciences Education, 18(1), ar9.

Lo, S. M., \& Mendez, J. I. (2019). Learning-The evidence. In Simonson, S. R (Ed.), POGIL: An introduction to process oriented guided inquiry learning for those who wish to empower learners (pp. 85-110). Sterling, VA: Stylus.

Ma, J., \& Baum, S. (2016). Trends in community colleges: Enrollment, prices, student debt, and completion (College Board research brief). New York: College Board

Maunder, R. E. (2018). Student's peer relationships and their contribution to university adjustment: The need to belong in the university community. Journal of Further and Higher Education, 42(6), 756-768.

McCarron, G. P., \& Inkelas, K. K. (2006). The gap between educational aspirations and attainment for first-generation college students and the role of parental involvement. Journal of College Student Development, 47(5), 534-549.

McConnell, P. J. (2000). ERIC review: What community colleges should do to assist first-generation students. Community College Review, 28(3), 75-87.

McCormick, A. C., \& Zhao, C. M. (2005). Rethinking and reframing the Carnegie classification. Change: The Magazine of Higher Learning, 37(5), 51-57.

McMorran, C., Ragupathi, K., \& Luo, S. (2017). Assessment and learning without grades? Motivations and concerns with implementing gradeless learning in higher education. Assessment \& Evaluation in Higher Education, 42(3), 361-377.

Mehta, S. S., Newbold, J. J., \& O'Rourke, M. A. (2011). Why do first-generation students fail? College Student Journal, 45(1), 20-36.

Miles, M. B., \& Huberman, A. M. (1984). Analysis during data collection. Qualitative data analysis: A sourcebook of new methods. Beverly Hills, CA Sage.

Mooney, G. M., \& Foley, D. J. (2011). Community colleges: Playing an important role in the education of science, engineering, and health graduates. National Center for Science and Engineering Statistics InfoBrief.

Mooring, R. D., \& Mooring, S. R. (2016). Predictors of timely baccalaureate attainment for underrepresented minority community college transfer 
students. Community College Journal of Research and Practice, 40(8), 681-694.

Moschetti, R. V., \& Hudley, C. (2015). Social capital and academic motivation among first-generation community college students. Community $\mathrm{Col}-$ lege Journal of Research and Practice, 39(3), 235-251.

Nasir, N. S., \& de Royston, M. M. (2013). Power, identity, and mathematical practices outside and inside school. Journal for Research in Mathematics Education, 44(1), 264-287.

Nasir, N. S., \& Saxe, G. B. (2003). Ethnic and academic identities: A cultural practice perspective on emerging tensions and their management in the lives of minority students. Educational Researcher, 32(5), 14-18.

National Academies of Sciences, Engineering, and Medicine. (2016). Barriers and opportunities for 2-year and 4-year STEM degrees: Systemic change to support students' diverse pathways. Washington, DC: National Academies Press.

National Science Foundation. (2019). Women, minorities, and persons with disabilities in science and engineering (NSF 19-304) (pp. 19-304). Alexandria, VA

Nerstad, C. G., Buch, R., Dysvik, A., \& Säfvenbom, R. (2020). Stability of individuals' definitions of success and the influence of perceived motivation al climate: A longitudinal perspective. Frontiers in Psychology, 11, 1326.

Ong, M., Smith, J. M., \& Ko, L. T. (2018). Counterspaces for women of color in STEM higher education: Marginal and central spaces for persistence and success. Journal of Research in Science Teaching, 55(2), 206-245.

Packard, B. W. L., Gagnon, J. L., LaBelle, O., Jeffers, K., \& Lynn, E. (2011) Women's experiences in the STEM community college transfer pathway. Journal of Women and Minorities in Science and Engineering, 17(2), 129-147.

Packard, B. W. L., \& Jeffers, K. C. (2013). Advising and progress in the community college STEM transfer pathway. NACADA Journal, 33(2), 65-76.

Pascarella, E. T., Pierson, C. T., Wolniak, G. C., \& Terenzini, P. T. (2004) First-generation college students: Additional evidence on college experiences and outcomes. Journal of Higher Education, 75(3), 249-284.

Pascarella, E. T., \& Terenzini, P. T. (2005). How college affects students: A third decade of research. San Francisco, CA: Jossey-Bass.

Patton, L. D. (2016). Disrupting postsecondary prose: Toward a critical race theory of higher education. Urban Education, 51(3), 315-342.

Patton, M. (1990). Qualitative evaluation and research methods (2nd ed.). Newbury Park, CA: Sage.

Pike, G. R., \& Kuh, G. D. (2005). First-and second-generation college students: A comparison of their engagement and intellectual development. Journal of Higher Education, 76(3), 276-300.

Pittman, L. D., \& Richmond, A. (2008). University belonging, friendship quality, and psychological adjustment during the transition to college. Journal of Experimental Education, 76(4), 343-362

President's Council of Advisors on Science and Technology. (2012). Engage to excel: Producing one million additional college graduates with degrees in science, technology, engineering and mathematics. Washington, DC: U.S. Government Office of Science and Technology.

Price, J. F., \& McNeill, K. L. (2013). Toward a lived science curriculum in intersecting figured worlds: An exploration of individual meanings in science education. Journal of Research in Science Teaching, 50(5), 501-529.

Ramsey, L. R., Betz, D. E., \& Sekaquaptewa, D. (2013). The effects of an academic environment intervention on science identification among women in STEM. Social Psychology of Education, 16(3), 377-397.

Rendon, L. I., \& Mathews, T. B. (1989). Success of community college students: Current issues. Education and Urban Society, 21(3), 312-327.

Reyes, M. E. (2011). Unique challenges for women of color in STEM transferring from community colleges to universities. Harvard Educational Review, 81(2), 241-263.

Roksa, J., \& Whitley, S. E. (2017). Fostering academic success of first-year students: Exploring the roles of motivation, race, and faculty. Journal of College Student Development, 58(3), 333-348.

Rubin, B. C. (2007). Learner identity amid figured worlds: Constructing (in) competence at an urban high school. Urban Review, 39(2), 217-249.

Saldaña, J. (2015). The coding manual for qualitative researchers (4th ed.). Thousand Oaks, CA: Sage.
Saunders, M., \& Serna, I. (2004). Making college happen: The college experiences of first-generation Latino students. Journal of Hispanic Higher Education, 3(2), 146-163.

Scanlon, L., Rowling, L., \& Weber, Z. (2007). "You don't have like an identity... you are just lost in a crowd": Forming a student identity in the first-year transition to university. Journal of Youth Studies, 10(2), 223-241.

Schinske, J. N., Balke, V. L., Bangera, M. G., Bonney, K. M., Brownell, S. E., Carter, R. S., ... \& Corwin, L. A. (2017). Broadening participation in biology education research: Engaging community college students and faculty. CBE-Life Sciences Education, 16(2), mr1. https://doi.org/10.1187/ cbe.16-10-0289

Seymour, E., \& Hewitt, N. M. (1997). Talking about leaving: Why undergraduates leave the sciences, Boulder, CO: Westview.

Seymour, E., \& Hunter, A-B. (2019). Talking about leaving revisited. New York, NY: Springer.

Shanahan, M. C. (2009). Identity in science learning: Exploring the attention given to agency and structure in studies of identity. Studies in Science Education, 45(1), 43-64.

Shaw, S. T., Spink, K., \& Chin-Newman, C. (2019). "Do I really belong here?": The stigma of being a community college transfer student at a four-year university. Community College Journal of Research and Practice, 43(9), 657-660.

Solorzano, D., Ceja, M., \& Yosso, T. (2000). Critical race theory, racial microaggressions, and campus racial climate: The experiences of African American college students. Journal of Negro Education, 69(1), $60-73$.

Spady, W. G. (1970). Dropouts from higher education: An interdisciplinary review and synthesis. Interchange, 1(1), 64-85.

Spencer, S. J., Logel, C., \& Davies, P. G. (2016). Stereotype threat. Annual Review of Psychology, 67, 415-437.

Spronken-Smith, R., Mirosa, R., \& Darrou, M. (2014). "Learning is an endless journey for anyone": Undergraduate awareness, experiences and perceptions of the research culture in a research-intensive university. Higher Education Research \& Development, 33(2), 355-337.

Starobin, S. S., Smith, D. J., \& Santos Laanan, F. (2016). Deconstructing the transfer student capital: Intersect between cultural and social capital among female transfer students in STEM fields. Community College Journal of Research and Practice, 40(12), 1040-1057.

Steele, C. M., \& Aronson, J. (1995). Stereotype threat and the intellectual test performance of African Americans. Journal of Personality and Social Psychology, 69(5), 797.

Stephens, N. M., Hamedani, M. G., \& Destin, M. (2014). Closing the social-class achievement gap: A difference-education intervention improves first-generation students' academic performance and all students' college transition. Psychological Science, 25(4), 943-953.

Terenzini, P. T., Springer, L., Yaeger, P. M., Pascarella, E. T., \& Nora, A. (1996) First-generation college students: Characteristics, experiences, and cognitive development. Research in Higher Education, 37(1), 1-22.

Tobolowsky, B., \& Cox, B. (2012). Rationalizing neglect: An institutional response to transfer students. Journal of Higher Education, 83(3), 389410

Tocci, C. (2010). An immanent machine: Reconsidering grades, historical and present. Educational Philosophy and Theory, 42(7), 762-778

Torres, L., Driscoll, M. W., \& Burrow, A. L. (2010). Racial microaggressions and psychological functioning among highly achieving African-Americans: A mixed-methods approach. Journal of Social and Clinical Psychology, 29(10), 1074-1099.

Townley, G., Katz, J., Wandersman, A., Skiles, B., Schillaci, M. J., Timmerman, B. E., \& Mousseau, T. A. (2013). Exploring the role of sense of community in the undergraduate transfer student experience. Journal of Community Psychology, 41(3), 277-290.

Townsend, B. K. (2008). "Feeling like a freshman again": The transfer student transition. New Directions for Higher Education, 2008(144), 69-77.

Townsend, B. K., \& Wilson, K. (2006). "A hand hold for a little bit": Factors facilitating the success of community college transfer students to a large research university. Journal of College Student Development, 47(4), 439-456.

Urrieta, L. (2007). Figured worlds and education: An introduction to the special issue. Urban Review, 39(2), 107-116. 
Walkington, L. (2017). How far have we really come? Black women faculty and graduate students' experiences in higher education. Humboldt Journal of Social Relations, 39, 51-65.

Wenger, E. (1998). Communities of practice: Learning, meaning, and identity New York: Cambridge University Press.

Wenger, E. (2010). Communities of practice and social learning systems: The career of a concept. In Blackmore, C. (Ed.), Social learning systems and communities of practice (pp. 179-198). London: Springer.

Volkwein, J. F., King, M. C., \& Terenzini, P. T. (1986). Student-faculty relationships and intellectual growth among transfer students. Journal of Higher Education, 57(4), 413-430.
Vryonides, M. (2007). Social and cultural capital in educational research: Is sues of operationalisation and measurement. British Educational Research Journal, 33(6), 867-885.

York-Anderson, D. C., \& Bowman, S. L. (1991). Assessing the knowledge of first-generation and second-generation college students. Journal of College Student Development, 32(2), 116-122.

Yosso, T. J. (2005). Whose culture has capital? A critical race theory discus sion of community cultural wealth. Race Ethnicity and Education, 8(1), 69-91.

Zamani, E. M. (2001). Institutional responses to barriers to the transfer process. New Directions for Community Colleges, 2001(114), 15-24. 